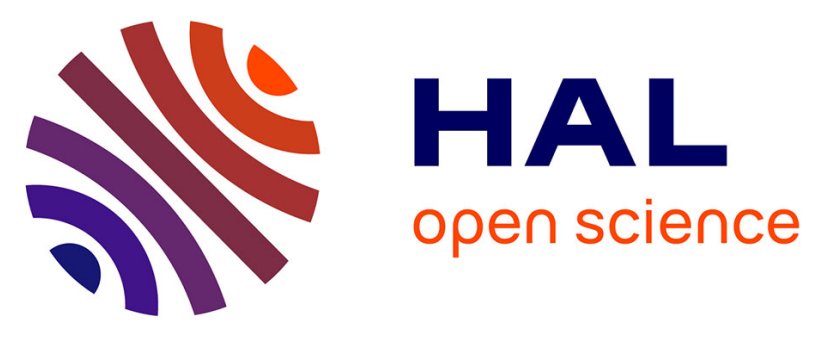

\title{
Effects of radionuclide contamination on leaf litter decomposition in the Chernobyl exclusion zone
}

\author{
Jean-Marc Bonzom, Stephan Hättenschwiler, Catherine Lecomte-Pradines, \\ Eric Chauvet, Sergey Gaschak, Karine Beaugelin-Seiller, Claire Della-Vedova, \\ Nicolas Dubourg, Andrey Maksimenko, Jacqueline Garnier-Laplace, et al.
}

\section{To cite this version:}

Jean-Marc Bonzom, Stephan Hättenschwiler, Catherine Lecomte-Pradines, Eric Chauvet, Sergey Gaschak, et al.. Effects of radionuclide contamination on leaf litter decomposition in the Chernobyl exclusion zone. Science of the Total Environment, 2016, vol. 562, pp. 596-603. 10.1016/j.scitotenv.2016.04.006 . hal-01346001

\author{
HAL Id: hal-01346001 \\ https://hal.science/hal-01346001
}

Submitted on 18 Jul 2016

HAL is a multi-disciplinary open access archive for the deposit and dissemination of scientific research documents, whether they are published or not. The documents may come from teaching and research institutions in France or abroad, or from public or private research centers.
L'archive ouverte pluridisciplinaire HAL, est destinée au dépôt et à la diffusion de documents scientifiques de niveau recherche, publiés ou non, émanant des établissements d'enseignement et de recherche français ou étrangers, des laboratoires publics ou privés. 


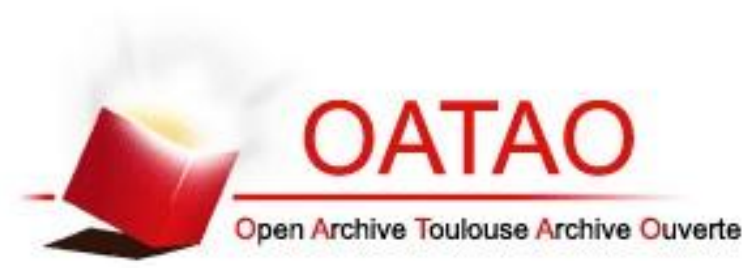

\section{Open Archive TOULOUSE Archive Ouverte (OATAO)}

OATAO is an open access repository that collects the work of Toulouse researchers and makes it freely available over the web where possible.

This is an author-deposited version published in : http://oatao.univ-toulouse.fr/ Eprints ID : 15744

To link to this article : $10.1016 / j$.scitotenv.2016.04.006

URL : http://dx.doi.org/10.1016/j.scitotenv.2016.04.006

To cite this version : Bonzom, Jean-Marc and Hättenschwiler, Stephan and Lecomte-Pradines, Catherine and Chauvet, Eric and Gaschak, Sergey and Beaugelin-Seiller, Karine and Della-Vedova, Claire and Dubourg, Nicolas and Maksimenko, Andrey and GarnierLaplace, Jacqueline and Adam-Guillermin, Christelle Effects of radionuclide contamination on leaf litter decomposition in the Chernobyl exclusion zone. (2016) Science of the Total Environment, vol. 562. pp. 596-603. ISSN 0048-9697

Any correspondence concerning this service should be sent to the repository administrator: staff-oatao@ listes-diff.inp-toulouse.fr 


\title{
Effects of radionuclide contamination on leaf litter decomposition in the Chernobyl exclusion zone
}

\author{
Jean-Marc Bonzom ${ }^{\mathrm{a}, *}$, Stephan Hättenschwiler ${ }^{\mathrm{b}}$, Catherine Lecomte-Pradines ${ }^{\mathrm{a}}$, Eric Chauvet ${ }^{\mathrm{c}}$, \\ Sergey Gaschak ${ }^{\mathrm{d}}$, Karine Beaugelin-Seiller ${ }^{\mathrm{a}}$, Claire Della-Vedova ${ }^{\mathrm{a}}$, Nicolas Dubourg ${ }^{\mathrm{a}}$, Andrey Maksimenko ${ }^{\mathrm{d}}$, \\ Jacqueline Garnier-Laplace ${ }^{\text {a }}$, Christelle Adam-Guillermin ${ }^{\text {a }}$ \\ a Institut de Radioprotection et de Sûreté Nucléaire (IRSN), PRP-ENV/SERIS, Cadarache, Bât. 183, BP 3, 13115 St Paul-lez-Durance, France \\ b Centre d'Ecologie Fonctionnelle et Evolutive (CEFE UMR 5175, CNRS-Université de Montpellier-Université Paul-Valéry Montpellier-EPHE), 1919 Route de Mende, F-34293 Montpellier, Franc \\ ${ }^{c}$ EcoLab, Université de Toulouse, CNRS, UPS, INPT, 118 Route de Narbonne, 31062 Toulouse cedex, France \\ d Chernobyl Center for Nuclear Safety, Radioactive Waste and Radioecology, International Radioecology Laboratory, 07100 Slavutych, Ukraine
}

Keywords:

Decomposers

Dose rates

Ecosystem functioning

Ionizing radiation

Nuclear accident

Pollution

\section{A B S T R A C T}

The effects of radioactive contamination on ecosystem processes such as litter decomposition remain largely unknown. Because radionuclides accumulated in soil and plant biomass can be harmful for organisms, the functioning of ecosystems may be altered by radioactive contamination. Here, we tested the hypothesis that decomposition is impaired by increasing levels of radioactivity in the environment by exposing uncontaminated leaf litter from silver birch and black alder at (i) eleven distant forest sites differing in ambient radiation levels $(0.22-15 \mu \mathrm{Gy} \mathrm{h}-1)$ and (ii) along a short distance gradient of radioactive

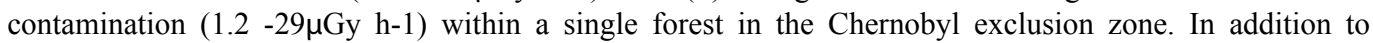
measuring ambient external dose rates, we estimated the average total dose rates (ATDRs) absorbed by decomposers for an accurate estimate of dose-induced ecological consequences of radioactive pollution. Taking into account potential confounding factors (soil $\mathrm{pH}$, moisture, texture, and organic carbon content), the results from the eleven distant forest sites, and from the single forest, showed increased litter mass loss with increasing ATDRs from 0.3 to $150 \mu \mathrm{Gy}$ h- 1 . This unexpected result may be due to (i) overcompensation of decomposer organisms exposed to radionuclides leading to a higher decomposer abundance (hormetic effect), and/or (ii) from preferred feeding by decomposers on the uncontaminated leaf litter used for our experiment compared to locally produced, contaminated leaf litter. Our data indicate that radiocontamination of forest ecosystems over more than two decades does not necessarily have detrimental effects on organic matter decay. However, further studies are needed to unravel the underlying mechanisms of the results reported here, in order to draw firrmer conclusions on how radio-contamination affects decomposition and associated ecosystem processes. 


\section{Introduction}

The major nuclear accident at the Chernobyl Nuclear Power Plant (ChNPP) in 1986 led to a total release of fission products (ignoring inert radioactive gases) into the atmosphere estimated at about $14 \times 10^{18} \mathrm{~Bq}$ (IAEA, 2006). This release and subsequent deposits resulted in a large-scale but heterogeneous radioactive contamination of territories according to the trajectories of the radioactive plume. The most affected natural and agricultural ecosystems are located within an area of about $4300 \mathrm{~km}^{2}$ around the damaged power plant known as the Chernobyl exclusion zone (CEZ).

Numerous studies have investigated the effects of ionizing radiation on wildlife from subcellular to community levels around the ChNPP (e.g. Møller and Mousseau, 2006; Geras'kin et al., 2008, 2013). However, the consequences of increased ionizing radiation levels on ecosystem processes such as plant production, the degradation of dead organic matter, and elemental cycling have received very little attention so far. The only existing study evaluating the influence of radioactive contamination on plant litter decomposition in the CEZ and adjacent areas reported decreased rates of leaf litter decomposition, resulting in an increasing thickness of the litter layer with increasing levels of ambient radiation (Mousseau et al., 2014). These results suggest a slower turnover of organic matter in response to higher levels of radioactivity, possibly due to negative impacts on the decomposer community.

Leaf litter decomposition plays a major role in ecosystem carbon and nutrient cycling (Swift et al., 1979; Cadish and Giller, 1997). Nutrients released during litter decomposition are estimated to account for 68 to $87 \%$ of the total annual requirement of essential elements for forest plant growth (Waring and Schlesinger, 1985). Decomposition is driven by a vast diversity of soil organisms including microorganisms and detritivorous invertebrates (e.g. Bardgett, 2005; Gessner et al., 2010). Depending on the quantity and quality of radionuclides accumulated in soil and litter, the resulting absorbed radiological dose (or dose rate) by soil organisms during their entire life and across generations may drive direct and/or indirect changes in various biological and ecological processes, including leaf litter decomposition (Geras'kin et al., 2008; Zaitsev et al., 2014). Indeed, within 2 months after the Chernobyl accident, $90 \%$ of soil invertebrate species had perished at a distance of 2 to $7 \mathrm{~km}$ from the ChNPP (Krivolutsky, 2000). In the first year after the accident, the total abundance of soil invertebrates in the forest litter was $45 \%$ of that of a reference site (Krivolutsky, 1996). However, the soil mesofauna communities were almost completely restored in terms of abundance and diversity 2.5 years after the accident, with the exception of the most severely contaminated sites (Krivolutsky, 1996, 2000). In contrast, Maksimova (2002) reported a diminished density and biomass of Diplopoda in forests exhibiting high contamination levels in the Gomel region (Belarus), $30 \mathrm{~km}$ North-East from the ChNPP, compared to control areas between 1986 and 1996. Very little data has been reported on the impact of the Chernobyl nuclear catastrophe on soil microbial community structure or biomass. For example, Romanovskaya et al. (1998) showed that the abundance and diversity of cellulolytic, nitrifying, and sulphate-reducing bacteria were 1 or 2 orders of magnitude lower in contaminated soils within a $10 \mathrm{~km}$ zone around the ChNPP compared to control soils, 7 to 9 years after the accident. Moreover, fungal community data collected around the ChNPP between 1990 and 2005 indicated that the fungi species richness declined with increasing ambient radiation level (see Dighton et al., 2008 for a review). In contrast, Chapon et al. (2012) showed that soil contaminated with radionuclides in the CEZ, exhibiting ${ }^{137} \mathrm{Cs}$ activities ranging from 61 to $750 \mathrm{~Bq} \mathrm{~g}^{-1}$, hosted a wide diversity of bacteria similar to that observed in nearby control soils with ${ }^{137} \mathrm{Cs}$ activities ranging from 0.35 to $1.5 \mathrm{~Bq} \mathrm{~g}^{-1}, 25$ years after the nuclear accident, suggesting recovery of bacterial communities.

Data on the consequences of radioactive contamination on soil organisms being scarce, it is presently difficult to predict how decomposition as a key process of ecosystem functioning may be affected by radionuclides in the environment. In the present study, we investigated the effects of radionuclide contamination in the CEZ on the decomposition of leaf litter from two tree species, silver birch (Betula pendula) and black alder (Alnus glutinosa) that are both highly abundant in the forests of the CEZ. The forested area has actually increased considerably since the establishment of the CEZ. Only 15 years after the nuclear disaster and the evacuation of residents, the forested area covered $70 \%$ of the total CEZ compared to $53 \%$ before the nuclear disaster (IAEA, 2001). Much of this forested area is covered by the early successional species silver birch and black alder. We exposed leaf litter collected in uncontaminated sites from uncontaminated trees to different levels of soil radioactive contamination. In addition, we estimated the average total dose rates (ATDRs) absorbed by decomposer communities based on soil radioactivity measurements. We hypothesized that leaf litter mass-loss decreases with increasing ATDRs, due to an impact on the decomposer communities.

\section{Materials and methods}

\subsection{Study sites}

A total of 11 deciduous forest sites were selected within the Chernobyl exclusion zone (CEZ; see materials and methods in the Supplementary text for detailed description) with distances among sites ranging between 1 and $50 \mathrm{~km}$ (=sites 1 to 11 ; Fig. 1 ). The dominant tree species at all sites were silver birch and black alder. The sites were chosen based on a similar vegetation cover and a gradient of ambient dose rates (Table 1). We established a second gradient of soil contamination along a short distance transect (site T, Fig. 1) within one single forest (approximately $300 \mathrm{~m}$ between two successive sampling points), in order to further reduce the variability of potential environmental confounding variables such as vegetation cover or soil characteristics (Fig. 1). This second gradient covered a range of radioactive contamination similar to the first gradient, with a total of 6 sampling points (A, B, C $\mathrm{D}, \mathrm{E}$, and F; Table 2). The dominant tree species at this site T were scots pine (Pinus sylvestris), sessile oak (Quercus petraea), and European hornbeam (Carpinus betulus), with sweet cherry (Prunus avium) and silver birch at lower abundances.

\subsection{Leaf litter decomposition experiment}

In October 2010, leaf litters of silver birch and black alder were collected outside the CEZ, near Slavutych town (i.e. $55 \mathrm{~km}$ East from Chernobyl) in uncontaminated sites. The leaves were collected at the time of abscission by shaking numerous trees and intercepting falling leaf on sheets of fabric $(3 \times 4 \mathrm{~m})$. Leaves were dried at $35^{\circ} \mathrm{C}$ during $72 \mathrm{~h}$, and stored at $20-25{ }^{\circ} \mathrm{C}$ until use. They were thoroughly mixed within species, after the selection of only clean and intact leaves.

At the eleven different forest sites and at site T, custom-made microcosms and litter bags with leaf litter were installed, respectively. Both 


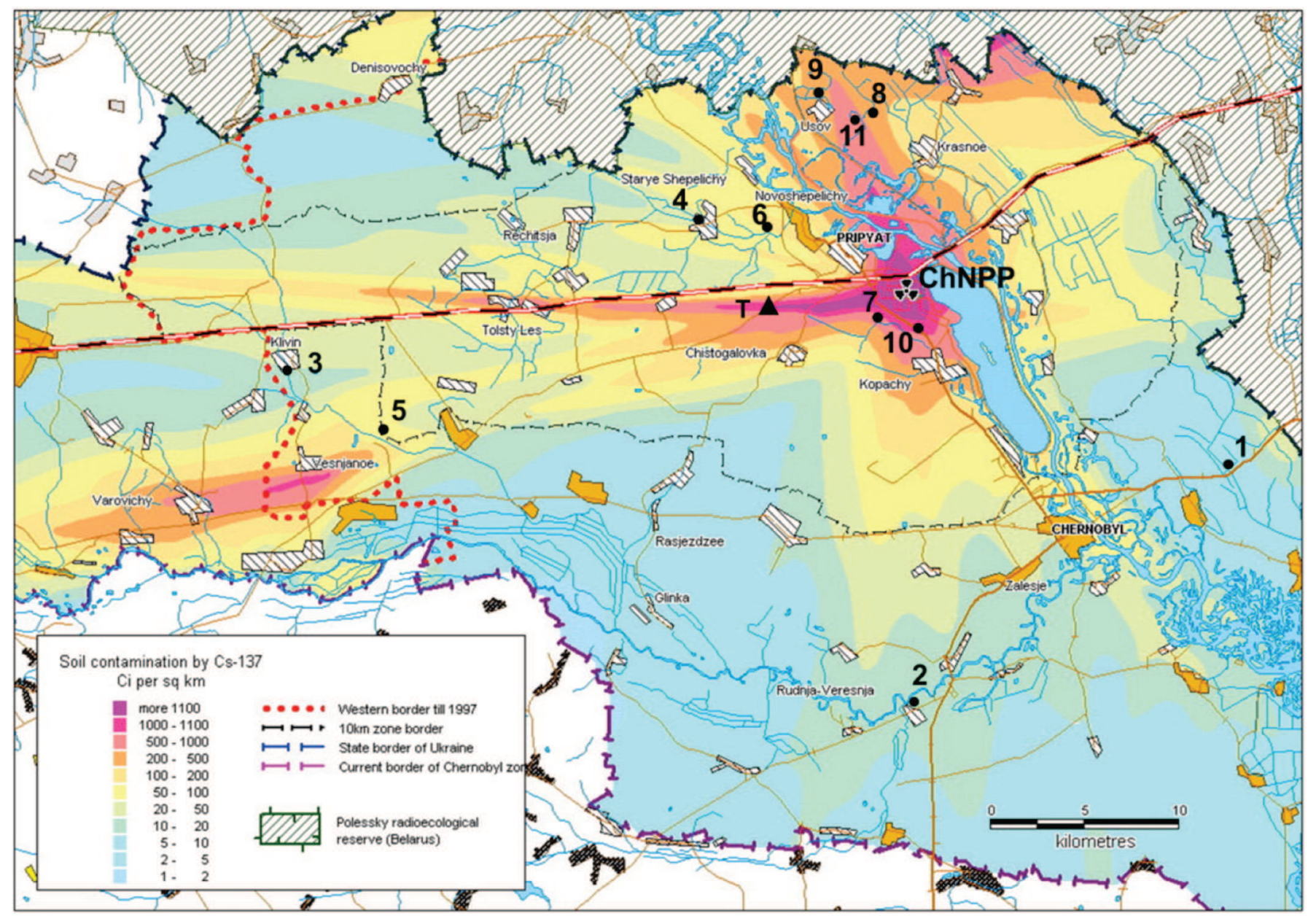

Fig. 1. Location of study area in the Chernobyl exclusion zone. Each sampling site was localised by GPS coordinates. Eleven forest sites with similar structure and species composition but presenting a gradient of radioactive contamination were selected ( sites 1,2,3,4, 5, 6, 7, 8, 9, 10, and 11). An additional site with a gradient of radioactive contamination over a very short distance within a single forest was chosen $\left(\boldsymbol{\Delta}\right.$ site T). The map shows the surface-ground contamination by ${ }^{137} \mathrm{Cs}$ expressed as $\mathrm{Ci}_{\text {per }} \mathrm{km}{ }^{2}\left(1 \mathrm{Ci}\right.$ per $\mathrm{km}^{2}=3.7 \times 10^{10} \mathrm{~Bq}$ per km $\left.{ }^{2}\right)$. This map also shows the location of the Chernobyl Nuclear Power Plant ( 4 ChNPP).

Adapted from Shestopalov (1996).

microcosms and litter bags had a mesh size of $1 \mathrm{~cm}$ allowing access to the entire decomposer community (including soil macrofauna). Field microcosms ( $15 \mathrm{~cm}$ in diameter and $15 \mathrm{~cm}$ height) were constructed from plastic cylinders according to Barantal et al. (2011) (see materials and methods in the Supplementary text for detailed description:
Fig. A.1). Microcosms were filled with $5 \pm 0.02 \mathrm{~g}$ (air-dry mass; average $\pm 1 \mathrm{SD}$ ) of tree leaf litter and placed randomly at each of the 11 sites during November 2010. At each site, we removed the natural litter and placed a total of twelve microcosms filled with birch or alder litter (six microcosms each) on the soil surface, yielding a total of 132

Table 1

Ambient dose rates at the forest sites (number 1 to 11) in the Chernobyl exclusion zone (Fig. 1). These measurements were conducted on the top soil using radiophotoluminescent glass dosimeters. The radionuclide concentrations measured in the soil samples collected from the top $0-10 \mathrm{~cm}$ layer (mean $\pm \mathrm{SE}$ ), and the average total dose rates (ATDR) estimated for decomposers are also indicated.

\begin{tabular}{|c|c|c|c|c|c|c|c|c|c|}
\hline \multirow[t]{2}{*}{ Sites } & \multirow{2}{*}{$\begin{array}{l}\text { Ambient dose rate } \\
\left(\mu G y h^{-1}\right)\end{array}$} & \multirow{2}{*}{$\begin{array}{l}\text { ATDR } \\
\left(\mu G y h^{-1}\right)\end{array}$} & \multicolumn{7}{|c|}{ Radionuclide concentrations ( $\left.\mathrm{kBq} \mathrm{kg}^{-1} \mathrm{DM}\right)$} \\
\hline & & & ${ }^{137} \mathrm{Cs}$ & ${ }^{90} \mathrm{Sr}$ & ${ }^{241} \mathrm{Am}$ & ${ }^{239,240} \mathrm{Pu}$ & ${ }^{238} \mathrm{Pu}$ & ${ }^{234} \mathrm{U}$ & ${ }^{238} \mathrm{U}$ \\
\hline 1 & $0.22 \pm 0.02$ & 0.3 & $0.4 \pm 0.04$ & $0.29 \pm 0.05$ & $0.008 \pm 0.002$ & $0.006 \pm 0.002$ & $0.003 \pm 0.001$ & $0.002 \pm 0.001$ & $0.002 \pm 0.001$ \\
\hline 2 & $0.32 \pm 0.04$ & 0.9 & $1.6 \pm 0.2$ & $0.41 \pm 0.06$ & $0.029 \pm 0.005$ & $0.017 \pm 0.004$ & $0.007 \pm 0.002$ & $0.011 \pm 0.004$ & $0.011 \pm 0.004$ \\
\hline 3 & $0.38 \pm 0.03$ & 1.1 & $2.1 \pm 0.2$ & $0.41 \pm 0.06$ & $0.028 \pm 0.005$ & $0.034 \pm 0.011$ & $0.017 \pm 0.005$ & $0.002 \pm 0.000$ & $0.001 \pm 0.000$ \\
\hline 4 & $0.86 \pm 0.06$ & 1.8 & $3.5 \pm 0.4$ & $0.98 \pm 0.15$ & $0.053 \pm 0.009$ & $0.029 \pm 0.006$ & $0.029 \pm 0.006$ & $0.003 \pm 0.001$ & $0.002 \pm 0.001$ \\
\hline 5 & $1.2 \pm 0.1$ & 2.1 & $7.0 \pm 1.0$ & $0.71 \pm 0.11$ & $0.038 \pm 0.009$ & $0.032 \pm 0.012$ & $0.004 \pm 0.001$ & $0.005 \pm 0.001$ & $0.004 \pm 0.001$ \\
\hline 6 & $2.1 \pm 1.1$ & 4.6 & $5.6 \pm 0.6$ & $2.0 \pm 0.3$ & $0.15 \pm 0.02$ & $0.18 \pm 0.06$ & $0.090 \pm 0.028$ & $0.003 \pm 0.001$ & $0.003 \pm 0.001$ \\
\hline 7 & $4.1 \pm 0.8$ & 7.9 & $6.6 \pm 0.7$ & $8.2 \pm 1.2$ & $0.29 \pm 0.04$ & $0.093 \pm 0.021$ & $0.043 \pm 0.009$ & $0.004 \pm 0.002$ & $0.003 \pm 0.001$ \\
\hline 8 & $5.6 \pm 0.4$ & 23 & $25 \pm 3$ & $20 \pm 3$ & $0.91 \pm 0.13$ & $0.35 \pm 0.11$ & $0.16 \pm 0.05$ & $0.006 \pm 0.001$ & $0.003 \pm 0.001$ \\
\hline 9 & $7.3 \pm 0.4$ & 21 & $34 \pm 3$ & $13 \pm 2$ & $0.98 \pm 0.13$ & $0.28 \pm 0.06$ & $0.13 \pm 0.03$ & $0.004 \pm 0.001$ & $0.002 \pm 0.001$ \\
\hline 10 & $12 \pm 1$ & 75 & $57 \pm 6$ & $90 \pm 14$ & $2.3 \pm 0.3$ & $0.60 \pm 0.16$ & $0.26 \pm 0.07$ & $0.006 \pm 0.002$ & $0.004 \pm 0.001$ \\
\hline 11 & $15 \pm 1$ & 43 & $38 \pm 4$ & $50 \pm 8$ & $1.5 \pm 0.2$ & $0.28 \pm 0.04$ & $0.12 \pm 0.02$ & $0.010 \pm 0.002$ & $0.006 \pm 0.001$ \\
\hline $\mathrm{MCI}$ & & & $62.0 \pm 5$ & $35.0 \pm 5$ & $1.5 \pm 0.13$ & $0.8 \pm 0.15$ & $0.4 \pm 0.08$ & $0.1 \pm 0.05$ & $0.1 \pm 0.05$ \\
\hline
\end{tabular}

DM: dry mass of soil.

$\mathrm{MCI}$ corresponds to the mean contribution in \% for each isotope to the total activity $\pm \mathrm{SE}$. 
Table 2

Ambient dose rates at the six stations along the transect located on the forest site named T in the Chernobyl exclusion zone (Fig. 1). These measurements were conducted on the top soil using radiophotoluminescent glass dosimeters. The radionuclide concentrations measured in the soil samples collected from the top $0-10 \mathrm{~cm}$ layer, and the average total dose rates (ATDR) estimated for decomposers are also indicated.

\begin{tabular}{|c|c|c|c|c|c|c|c|c|c|}
\hline \multirow[t]{2}{*}{ Stations } & \multirow{2}{*}{$\begin{array}{l}\text { Ambient dose rate } \\
\left(\mu \mathrm{Gy} \mathrm{h} \mathrm{h}^{-1}\right)\end{array}$} & \multirow{2}{*}{$\begin{array}{l}\text { ATDR } \\
\left(\mu G y h^{-1}\right)\end{array}$} & \multicolumn{7}{|c|}{ Radionuclide concentrations ( $\left.\mathrm{kBq} \mathrm{kg}^{-1} \mathrm{DM}\right)$} \\
\hline & & & ${ }^{137} \mathrm{Cs}$ & ${ }^{90} \mathrm{Sr}$ & ${ }^{241} \mathrm{Am}$ & ${ }^{239,240} \mathrm{Pu}$ & ${ }^{238} \mathrm{Pu}$ & ${ }^{234} \mathrm{U}$ & ${ }^{238} \mathrm{U}$ \\
\hline A & $1.2 \pm 0.03$ & 23 & $15 \pm 3$ & $17 \pm 2$ & $1.5 \pm 0.7$ & $0.34 \pm 0.05$ & $0.16 \pm 0.02$ & $0.005 \pm 0.001$ & $0.004 \pm 0.001$ \\
\hline B & $1.4 \pm 0.05$ & 24 & $14 \pm 3$ & $21 \pm 4$ & $1.3 \pm 0.7$ & $0.40 \pm 0.11$ & $0.19 \pm 0.05$ & $0.004 \pm 0.001$ & $0.003 \pm 0.001$ \\
\hline C & $3.3 \pm 0.08$ & 63 & $45 \pm 4$ & $83 \pm 16$ & $0.58 \pm 0.08$ & $0.99 \pm 0.27$ & $0.43 \pm 0.11$ & $0.006 \pm 0.001$ & $0.005 \pm 0.001$ \\
\hline D & $6.0 \pm 1.01$ & 80 & $80 \pm 3$ & $97 \pm 5$ & $1.0 \pm 0.2$ & $1.1 \pm 0.1$ & $0.48 \pm 0.04$ & $0.006 \pm 0.001$ & $0.004 \pm 0.001$ \\
\hline E & $12 \pm 1$ & 150 & $128 \pm 13$ & $210 \pm 70$ & $1.5 \pm 0.4$ & $1.2 \pm 0.4$ & $0.53 \pm 0.19$ & $0.008 \pm 0.001$ & $0.004 \pm 0.001$ \\
\hline $\mathrm{F}$ & $29 \pm 2$ & 91 & $129 \pm 23$ & $92 \pm 24$ & $2.6 \pm 0.6$ & $0.69 \pm 0.20$ & $0.27 \pm 0.10$ & $0.010 \pm 0.001$ & $0.004 \pm 0.001$ \\
\hline $\mathrm{MCI}$ & & & $42.7 \pm 3.4$ & $54.5 \pm 3.4$ & $1.8 \pm 0.7$ & $0.69 \pm 0.13$ & $0.01 \pm 0.002$ & $0.01 \pm 0.002$ & $0.005 \pm 0.002$ \\
\hline
\end{tabular}

DM: dry mass of soil.

$\mathrm{MCI}$ corresponds to the mean contribution in \% for each isotope to the total activity $\pm \mathrm{SE}$.

microcosms ( 3 replicate microcosms $\times 2$ litter species $\times 2$ harvest dates $\times 11$ sites). Half of all microcosms were removed after 162 days (i.e. at the end of April 2011), and the other half after 321 days of exposure (i.e. in early October 2011). A total of 37 microcosms were lost probably due to wildlife activity. Ten litter bags were filled with $7 \pm$ $0.10 \mathrm{~g}$ of silver birch litter (dry mass; average $\pm 1 \mathrm{SD}$ ), and placed at each of the six sampling points in November 2010, (see material and methods in the Supplementary text: Fig. A.2). Litter bags were retrieved after 318 days of exposure in the field. Upon litter harvest, remaining leaf litter was gently rinsed with water to remove adhering soil particles, dried at $60^{\circ} \mathrm{C}$ for $48 \mathrm{~h}$ and weighed. Conversion of air dry to oven dry initial litter mass was done based on five subsamples of initial litter.

\subsection{Soil sampling}

We randomly collected 10 soil cores $(2.5 \mathrm{~cm}$ in diameter $\times 10 \mathrm{~cm}$ deep) at each of the eleven forest sites in April 2011. Soil samples were sieved ( $2 \mathrm{~mm}$ mesh) and pooled across the 10 samples per site. Similarly, we collected 15 soil cores from the six points along the transect at site $\mathrm{T}$ (sieved at $2 \mathrm{~mm}$ and pooled per sampling point) in October 2011. Following the method by Lecomte-Pradines et al. (2014), subsamples of these pooled soil samples were used to analyse soil characteristics (moisture, $\mathrm{pH}$, total organic carbon $\left(\mathrm{C}_{\text {org }}\right.$ ), particle size distribution (PSD): Table 3, and radionuclide concentrations; see material and methods in the Supplementary text for detailed description of these methods).

\subsection{Ambient radiation levels and radionuclide concentrations in soil}

Radiophotoluminescent (RPL) glass dosimeters (Chiyoda Technol Corporation, Japan, model GBFJ01) with an FGD-660 reader (measuring only energy gamma radiation) were used for in situ monitoring of the ambient radiation dose at each site (Juto, 2012). RPL dosimeters were placed on the soil surface beside six randomly selected microcosms at each site, and of six randomly selected litter bags at each sampling point of site T. The dosimeters integrated radiation dose over 6 months (left in the field from April to September). All analyses were performed by the Dosimetry Laboratory (IRSN,
France). In parallel, the "background" correction was assessed via five RPL dosimeters transported from IRSN (Saint-Paul-lez-Durance, France) to the International Radiological Laboratory-SSRI (Slavutych, Ukraine) and left there for the duration of the study.

The measurement of radionuclide $\left({ }^{137} \mathrm{Cs},{ }^{90} \mathrm{Sr},{ }^{238} \mathrm{Pu},{ }^{239}+{ }^{240} \mathrm{Pu}\right.$, ${ }^{234} \mathrm{U},{ }^{238} \mathrm{U}$, and ${ }^{241} \mathrm{Am}$ ) content in soil samples was carried out in the IRL-SSRI laboratory (Slavutych, Ukraine) using standard methods (see materials and methods in the Supplementary text).

\subsection{Decomposer total dose rate estimations}

We also estimated the total absorbed dose rate (TDR) by decomposers considering both external and internal irradiation pathways. Moreover, unlike RPL dosimeter data, these estimates allow consideration of the contribution of all radionuclides and radiation types (alpha, beta and gamma) (Lecomte-Pradines et al., 2014).

The TDR corresponds to the energy deposited into the body of decomposers per unit of time. Considered radiation sources are external (i.e. surrounding contaminated environment such as soil), and internal (following ingestion, or dermal absorption). This latter exposure pathway appears relevant as decomposer organisms spend a considerable amount of time in intimate contact with the soil, ingest soil particles and feed also in the surroundings of the field microcosms and litterbags filled with un-contaminated leaf litter. The intensity of this deposit is a function of radiation energy, as well as of the organisms' shape, composition, and behaviour (Beaugelin-Seiller et al., 2006).

We limited the TDR estimates to four key groups of organisms influencing decomposition: microorganisms, as the predominant decomposers, nematodes and earthworms as two groups of invertebrates living mainly in soil, and isopods living and feeding in the litter layer. From these group-specific TDRs, we estimated the average TDRs of decomposers (ATDR). We estimated the radionuclide activities for each of the four groups of decomposers from the soil activity concentrations by applying equilibrium-based concentration ratios (CRs). These values were taken from the ERICA tool database (Version 1.2.0 - Updated 2010.12.01 for detritivorous invertebrate, Beresford et al., 2007) (Supplementary Table A.1). We then calculated external and internal dose conversion coefficients

Table 3

Physico-chemical characteristics of the soil in 11 forest sites, and in 6 stations along a transect in a forest with a gradient of radionuclide contamination ( $=$ site $\mathrm{T}$ ).

\begin{tabular}{|c|c|c|c|c|c|c|}
\hline & \multicolumn{3}{|c|}{ Forest sites (sites 1 to 11 ) } & \multicolumn{3}{|c|}{ Transect (site T, points A to E) } \\
\hline & Mean \pm SD & Median & Range & Mean \pm SD & Median & Range \\
\hline $\mathrm{SM}\left(\% \mathrm{H}_{2} \mathrm{O}\right)$ & $20.2 \pm 7.9$ & 18.4 & $8.7-32$ & $39.6 \pm 9$ & 43.1 & $21-49$ \\
\hline Soil pH & $4.3 \pm 0.5$ & 4.2 & $3.6-5.2$ & $3.6 \pm 0.1$ & 3.5 & $3.5-3.8$ \\
\hline $\mathrm{C}_{\mathrm{org}}\left(\mathrm{mg} \cdot \mathrm{g}^{-1} \mathrm{DW}\right)$ & $12.0 \pm 8.4$ & 9.2 & $8.7-32$ & $39.0 \pm 12$ & 42.6 & $15-50.4$ \\
\hline PSD (DV50, $\mu \mathrm{m})$ & $168.2 \pm 68.0$ & 204.8 & $56-243.4$ & $132.4 \pm 28$ & 115.0 & $113.5-189$ \\
\hline
\end{tabular}

$\mathrm{SM}=$ soil moisture; $\mathrm{C}_{\mathrm{org}}=$ soil extractable organic carbon; $\mathrm{PSD}=$ soil particle size distribution. 
(DCCs) for each combination (radionuclide, decomposer) according to ecologically plausible exposure scenarios (Supplementary Table A.2) using EDEN software version 2.3 (Beaugelin-Seiller et al. 2006). DCCs allow conversion of the activity of a radionuclide in an organism (Bq unit mass ${ }^{-1}$ ) into a dose rate (Gy unit time ${ }^{-1}$ ) and are thus specific for each radionuclide-organism combination. At the end, we calculated TDR absorbed by each of the four groups of decomposers, expressed in $\mu \mathrm{Gy} \mathrm{h} \mathrm{h}^{-1}$ (for more detailed information see Supplementary text: Total dose calculations).

\subsection{Statistical analyses}

Linear regressions were run to estimate the consistency between external radiation levels $\left(\mu \mathrm{Gy} \mathrm{h}{ }^{-1}\right)$ measured by RPL dosimeters and estimated ATDRs.

To assess the relationship between leaf litter mass loss and ATDRs we ran analyses of covariance (ANCOVA). The ANCOVA allowed us to determine whether there were any significant differences between the means of independent groups, while accounting for potential confounding factors (i.e. soil moisture, $\mathrm{pH}, \mathrm{C}_{\mathrm{org}}$, particle size distribution). These four environmental variables were incorporated in the model as one variable based on the coordinates from the first axis of a principal component analysis, which accounted for $65 \%$ and $80 \%$ of the total variance for the 11 forest sites and site $\mathrm{T}$, respectively. In the analysis for the 11 forest sites, ATDRs, tree species identity of leaf litter and sampling dates were treated as fixed factors and soil physico-chemical characteristics as covariates. For site T, we ran a similar ANCOVA with ATDRs as the fixed factor and soil physico-chemical characteristics as covariates. Following the ANCOVAs, when a significant effect of ATDR on leaf litter mass loss was found, we ran a simple linear regression to further explore the relationship between these two variables. Percentages of leaf mass loss were $\log _{10}$ transformed prior to analyses to meet the conditions of the analyses, i.e., being normally distributed and having homogeneous variance. All statistical analyses were performed using the statistical software SPSS version 19 (IBM).

\section{Results}

3.1. Soil radionuclide concentrations and estimated decomposer total dose rates

${ }^{137} \mathrm{Cs},{ }^{90} \mathrm{Sr},{ }^{241} \mathrm{Am}$, and ${ }^{238,239,240} \mathrm{Pu}$ concentrations in the top soil (upper $10 \mathrm{~cm}$ ) increased from site 1 to site 11 (Table 1 ). ${ }^{137} \mathrm{Cs}$ and ${ }^{90} \mathrm{Sr}$ dominated activity concentrations with an average of $62.0 \pm 5 \%$ and $35.0 \pm 5 \%$ of the total activity concentration, respectively (Table 1).

With ambient dose rates measured at the soil surface with RPL dosimeters ranging from 0.22 to $15 \mu \mathrm{Gy} \mathrm{h}{ }^{-1}$, the ATDRs at the eleven forest sites varied from 0.3 to $75 \mu \mathrm{Gy} \mathrm{h}{ }^{-1}$ (Table 1 ). External dose rates measured with RPL dosimeters and ATDR values were positively related $\left(\right.$ ATDR $\left.=4.06 \times \mathrm{RPL}-1.52 ; \mathrm{r}^{2}=0.87, \mathrm{p}<0.001\right)$. The estimated ATDRs were three-fold higher than RPL dosimetry measurements on average.

As for the eleven forest sites, the activity concentrations of isotopes measured in soil samples at site T were also dominated by ${ }^{137} \mathrm{Cs}$ and ${ }^{90} \mathrm{Sr}$, which contributed $42.7 \pm 3.4 \%$ and $54.5 \pm 3.4 \%$ to the total activity concentration (Table 2). While the activity concentrations of ${ }^{234,238} \mathrm{U}$ at site T were comparable to those measured at the eleven forest sites, the activity concentrations of ${ }^{90} \mathrm{Sr},{ }^{137} \mathrm{Cs},{ }^{241} \mathrm{Am}$, and ${ }^{238,239,240} \mathrm{Pu}$ were considerably higher at site $\mathrm{T}$ (Tables 1 and 2 ). Ambient dose rates at the soil surface ranged from 1.2 to $29 \mu \mathrm{Gy} \mathrm{h}{ }^{-1}$ along the contamination gradient at site T, which corresponds to a gradient in ATDRs between 23 and $150 \mu \mathrm{Gy} \mathrm{h}{ }^{-1}$ (Table 2). Again, dosimeter determined RPL and ATDR values showed a positive relationship $($ ATDR $=2.39 \times \mathrm{RPL}+45.87$ $\mathrm{r}^{2}=0.59, \mathrm{p}<0.001$ ). However, ATDRs were considerably higher than RPL dose rates compared to the eleven forest sites with an average fourteen-fold higher ATDR compared to RPL dose rates.

\subsection{Leaf litter mass loss}

At the eleven forest sites, leaf litter from alder decomposed more rapidly than that from birch, irrespectively of sampling date and ATDRs (no significant interactions; Supplementary Table A.3). Not surprisingly, mass loss increased with time for litter from both tree species ( $p<0.001$; Supplementary Table A.3 Fig. 2A, B). After 162 days of exposure, the mean litter mass loss varied between 34 and $54 \%$, and between 22 and 36\%, for alder and birch, respectively. After 321 days of exposure, the species differences were essentially the same with a faster decomposition of alder leaf litter ( 45 to $87 \%$ mean mass loss) than birch leaf litter (25 to $59 \%$ mean mass loss; Fig. 2B). The physico-chemical soil parameters were not associated with mass loss ( $\mathrm{p}=0.928$; Supplementary Table A.3), but there was a significant positive effect of ATDRs on mass loss ( $p<0.001$; Supplementary Table A.3). However, the effect of ATDR differed between sampling dates (ATDRs $\times$ sampling date, $p<0.001$; Supplementary Table A.3). During the initial stage of decomposition, leaf litter from both tree species decomposed more rapidly with increasing ATDRs (Fig. 2A). In contrast, during the second stage of decomposition, ATDR had no longer a significant effect on mass loss of either species (Fig. 2B).

At site T, mass loss of birch leaf litter varied on average between 44 and $57 \%$ after 318 days of exposure in the field. This variation was significantly related to ATDR, with mass loss increasing with ATDR (Fig. 3). Similar to the eleven forest sites, we observed no association of the soil physico-chemistry with mass loss ( $\mathrm{p}=0.647$; Supplementary Table A.4).

\section{Discussion}

We initially hypothesized that long-term radiation exposure due to the Chernobyl accident, and thus a higher dose of radiation absorbed by decomposers in the Chernobyl exclusion zone (CEZ), would have negative effects on leaf litter decomposition. Our data do not support this hypothesis, as decomposition of leaf litter from two dominant tree species, birch and alder, increased with total dose rates estimated for decomposers (ATDRs). At the relatively large spatial scale covered by the eleven different forest sites, the positive relationship between exposure to radiation and litter mass loss was observed during the initial stage of decomposition, but disappeared after almost a year of decomposition in the field (Fig. 2). These responses were the same for the more rapidly decomposing alder litter and the more slowly decomposing birch litter, indicating that species identity and overall quality of the leaf litter had no apparent impact on how radioactivity affected decomposition. Contrary to our findings, a previous study on leaf litter decomposition around Chernobyl including rather slowly decomposing leaf litters (e.g. Quercus robur and Pinus sylvestris) showed a negative relationship between litter mass loss and the level of ambient radiation (Mousseau et al., 2014). These authors reported up to $40 \%$ lower mass losses in the most contaminated sites (ca. $240 \mu \mathrm{Gy} \mathrm{h}{ }^{-1}$ ) compared to sites with a normal background radiation level for Ukraine (ca. $0.09 \mu \mathrm{Gy} \mathrm{h}{ }^{-1}$ ) after 9 months of field exposure.

What could be the reasons for these contrasting results? An inherent difficulty with this type of field study is that other potentially confounding factors vary along with the studied independent variable - here ATDRs - that could influence the response variable, but which are difficult to control. For example, soil $\mathrm{pH}$, which has a major impact on soil processes ranged from 3.1 to 7.8 among sites in Mousseau et al.'s (2014) study, and from 3.6 to 5.2 in our study, which is a considerably smaller range (1.6 pH units in our study compared to $4.7 \mathrm{pH}$ units in the previous study). Even though we accounted for some environmental factors in our statistical models - as did Mousseau et al. (2014) - and did not see any indication of confounding effects, we cannot exclude the possibility that some unidentified factors could have had some influence. Our second gradient of varying radiation levels was at a much smaller spatial scale, and thus reduced environmental heterogeneity 

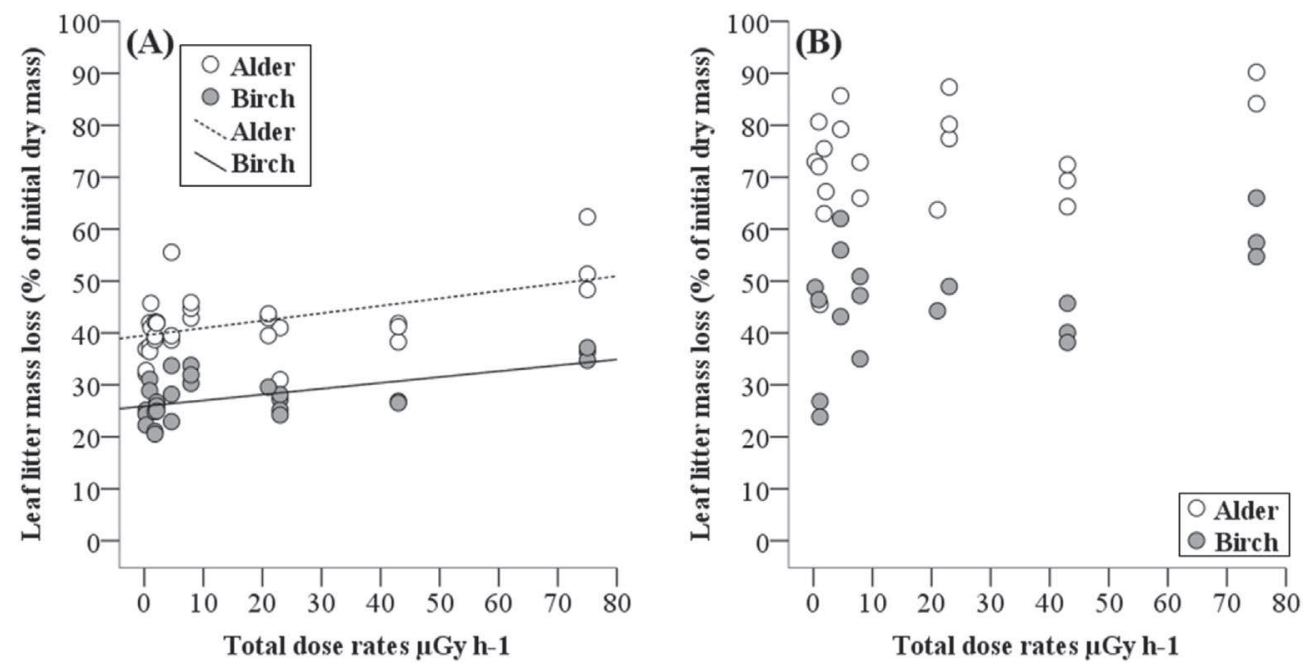

Fig. 2. Mass loss of leaf litter (percent of initial dry mass) from the two tree species birch (Betula pendula) and alder (Alnus glutinosa) as a function of the average total dose rates estimated for decomposers (ATDRs, $\mu \mathrm{Gy} \mathrm{h}{ }^{-1}$ ) at eleven different forest sites. (A) Mass loss after 162 days of exposure, and (B) after 321 days of exposure in the field. Lines represent simple linear regressions: alder: $F_{1,29}=9.689, \mathrm{p}=0.004$, mass loss $=1.595+0.001 \times \mathrm{ATDR}, \mathrm{r}^{2}=0.25$; birch: $F_{1,25}=12.019, \mathrm{p}=0.002$, mass loss $=1.411+0.002 \times \mathrm{ATDR}, \mathrm{r}^{2}=0.32(\mathrm{~A}) ;$ not significant (B).

and the potential for confounding factors substantially. Along this additional gradient varying in soil radionuclide contamination from 14 to $129 \mathrm{kBq} \mathrm{kg}{ }^{-1}{ }^{137} \mathrm{Cs}$ DM over $<2 \mathrm{~km}$ (Table A.2) within the same forest with identical structure and species composition, we observed the same positive relationship between mass loss of birch leaf litter (Fig. 3) and ATDRs, confirming our findings from the eleven forest sites.

One of the most important differences between our study and that of Mousseau et al. (2014) was the range in radiation levels. The sites selected by Mousseau et al. (2014) differed between 0.09 and $240 \mu \mathrm{Gy} \mathrm{h} \mathrm{h}^{-1}$ compared to our study sites ranging from 0.22 to $29 \mu \mathrm{Gy} \mathrm{h} \mathrm{h}^{-1}$. Actually, two sites among the most contaminated in Mousseau et al.'s (2014) study appeared to drive the negative relationship between mass loss and radiation level. This might suggest a threshold in contamination, above which the decomposer abundance and community composition might be affected more negatively by soil radioactive contamination. However, despite the use of more recalcitrant

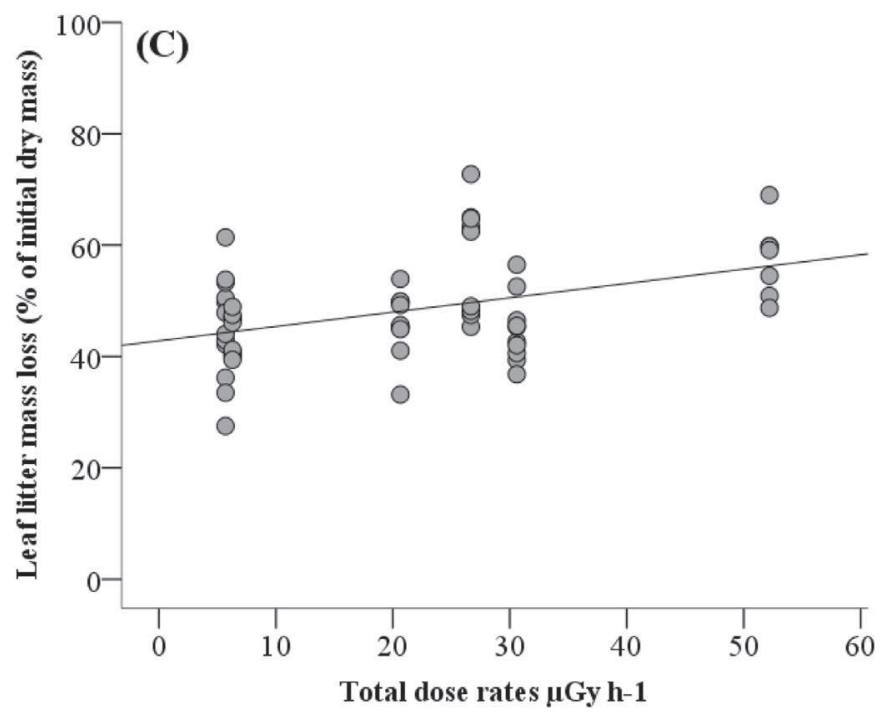

Fig. 3. Mass loss of birch leaf litter (percent of initial dry mass after 318 days of exposure in the field) as a function of the average total dose rates estimated for decomposers (ATDRs, $\mu \mathrm{Gy} \mathrm{h} \mathrm{h}^{-1}$ ) along a $1500 \mathrm{~m}$ transect located within a single forest stand. The black line represents a simple linear regression $\left(F_{1,57}=12.554, \mathrm{p}=0.001\right.$, mass loss $=$ $1.622+0.001 \times$ ATDR, $\left.r^{2}=0.18\right)$. litter material than in our study, Mousseau et al. (2014) reported 55 to $60 \%$ mass loss after 270 days of exposure in the field at the most contaminated sites, which is rather higher than what we observed for birch leaf litter after $>300$ days at the lowest contamination in both gradients. Actually, the data reported by Mousseau et al. (2014) suggest that leaf litter decomposition at some of the most contaminated sites around Chernobyl proceeds at rates comparable or higher to what is reported in the literature for the same or similar tree species at sites without any radioactive contamination (e.g. Berg et al., 1993; Prescott et al., 2000).

Previous studies investigating the effects of ionizing radiation on groups of organisms involved in litter decomposition showed weak or no effects. For instance, Murphy et al. (2011) found no relationship between ambient radiation dose rates (ranging from 0.1 to $30 \mu \mathrm{Gy} \mathrm{h}{ }^{-1}$ ) and the abundance and diversity of aquatic invertebrate communities sampled in eight lakes affected by Chernobyl fallout 17 years after the nuclear accident. Chapon et al. (2012) showed that both highly and weakly radio-contaminated soils host a wide diversity of bacteria, suggesting that long-term exposure to radionuclides does not lead to the erosion of bacterial diversity. Lecomte-Pradines et al. (2014) also found little effect from exposure to radiation in nematode abundance on soil samples collected at 18 forest sites (including the eleven sites studied here) in the CEZ ranging in ATDRs between 0.7 and $220 \mu \mathrm{Gy} \mathrm{h} \mathrm{h}^{-1}$ in 2011. Overall, these previous studies indicate that dose rates of up to around $30 \mu \mathrm{Gy} \mathrm{h} \mathrm{h}^{-1}$ - equivalent to $150 \mu \mathrm{Gy} \mathrm{h} \mathrm{h}^{-1}$ ATDRs - are unlikely to negatively affect the diversity and abundance of decomposer organisms. In contrast, the abundance of above-ground insects and spiders may be more susceptible to radiation (Møller and Mousseau, 2009).

Another potential reason for conflicting results may be related to technical aspects of the measurements. The contamination level measured with RPL dosimeters or instantaneous measurements with portable dosimeters may not provide biologically relevant information. For instance, the same dose rates of $12 \pm 1 \mu \mathrm{Gy} \mathrm{h}{ }^{-1}$ we measured with RPL dosimeters both at site 10 of the spatially larger gradient and site $\mathrm{E}$ in the spatially narrow transect corresponded to activity concentrations of ${ }^{137} \mathrm{Cs}$ of $57 \pm 6 \mathrm{kBq} \mathrm{kg}{ }^{-1} \mathrm{DM}$ at site 10 , and of $128 \pm$ $13 \mathrm{kBq} \mathrm{kg}^{-1} \mathrm{DM}$ at site E, i.e. about twice as high than at site 10 (Tables 1 and 2). The differences in ${ }^{90} \mathrm{Sr},{ }^{238,239,240} \mathrm{Pu}$ between these two sites showed the same trend. Such a disconnection between dosimeter data and activity concentrations may result from the presence of highly radioactive fine particles (IAEA, 1996; Zheltonozhsky et al., 
2001), called "hot particles", in soil samples collected at site T, which did not influence very much the field measurements with RPL dosimeters, but which were detectable by spectrometry. The presence of hot particles at site $\mathrm{T}$ likely originates from the radioactive cloud following the first thermal explosion of the reactor 4 , which generated a huge amount of fuel particles (Kashparov et al., 2003). Site T is located at $3.5 \mathrm{~km}$ of the West tip of the area known as Chernobyl's "Red forest", which is one of the most contaminated areas of the CEZ (Shestopalov, 1996). Also, ATDR estimates integrate the contribution of all radiation types (alpha, beta and gamma emitters) from all exposure pathways (internal and external) as opposed to ambient external dose rates measured with RPL dosimeters or a portable dosimeter, which were commonly used in previous studies (e.g. Møller and Mousseau, 2009; Mousseau et al., 2014). For an accurate assessment of the effects of radioactive pollution on biological processes, the total dose rates absorbed by organisms (here decomposer communities) are hence more meaningful than instantaneous dosimeter measurements, which mainly assess gamma radiation. This is particularly critical when several radioactive isotopes are present, with ${ }^{241} \mathrm{Am},{ }^{238,239,240} \mathrm{Pu},{ }^{234,238} \mathrm{U}$ being essentially $\alpha$-emitter, ${ }^{90} \mathrm{Sr} \beta$-emitter, and ${ }^{137} \mathrm{Cs} \gamma, \beta$-emitter.

Our finding of increasing mass loss of decomposing birch and alder leaf litter with increasing chronic irradiation is quite unexpected. Two non-exclusive mechanisms can be evoked which could potentially explain this surprising result. (i) Under any type of moderate stress (here radiological stress) organisms may overcompensate the impact of disturbance with increasing fitness, known as "hormetic effect" (Calabrese and Baldwin, 2002). For example, along a gradient of heavy metals concentrations ( $\mathrm{Zn}, \mathrm{Cu}$, and $\mathrm{Cd}$ ) in forest soils, Skubala and Kafel (2004) showed that the highest abundance of Oribatida, Gamasida, Actinedida, Acaridida, and Collembola was observed in forest characterized by moderate contamination of heavy metals, implying an increase in mesofauna abundance up to a certain level of metallic loads. Similarly, Bezrukov et al. (2015) reported positive relationships between radiation and abundance of some invertebrate taxa (Acari, Araneae, Formica sp., Homoptera) sampled with pit-fall traps at different sites within CEZ with ambient dose rates ranging from 0.13 to $360 \mu \mathrm{Gy} \mathrm{h}^{-1}$. Finally, Galván et al. (2014) observed that oxidative stress and DNA damage decreased in wild birds exposed to chronic low-dose radiation at CEZ. They concluded that birds may adapt to chronic exposure to ionizing radiation with a hormetic response. (ii) Because we used leaf litter material from uncontaminated control sites, decomposers may have preferred this exogenous leaf litter material over local leaf litter which may have a lower overall quality. Leaf litter quality is a major factor affecting decomposer communities (e.g. Melillo et al., 1982; Cornwell et al., 2008). Similar to the negative effect of heavy metal pollution on leaf litter quality and subsequently reduced decomposition rates (Killham and Wainwright, 1981; Berg et al., 1991; McEnroe and Helmisaari, 2001; Johnson and Hale, 2004), exposure to radionuclides may negatively affect leaf litter quality. Having the choice between the locally produced leaf litter material and the uncontaminated leaf litter of potentially higher quality, decomposer organisms may have shown a preference for the latter. Such a preference effect would be expected to increase with increasing radioactive exposure, i.e. decreasing local litter quality, which is in line with our observations. To test this hypothesis, future studies should assess quality differences along contamination gradients and compare decomposition between locally produced and exogenous leaf litter.

\section{Conclusion}

Our results suggest that in the CEZ forest ecosystems, 25 years after the Chernobyl nuclear accident, decomposition of leaf litter from the two dominant tree species black alder and silver birch was not negatively affected by chronic exposure to ionizing radiation of decomposers with ATDRs of up to $150 \mu \mathrm{Gy} \mathrm{h}{ }^{-1}$. Rather, our data indicate that leaf litter mass loss may increase with increasing ATDRs possibly resulting from overcompensation of decomposer organisms exposed to radionuclides, or from preferred feeding on the uncontaminated leaf litter we used in our study. Field studies exploring the potential effects of radioactive pollution on litter decomposition are extremely rare and they report conflicting results (this study and Mousseau et al., 2014). More investigations are needed for the understanding of underlying mechanisms of how radioactive contamination affects decomposition and other ecosystem processes in CEZ but also in other radio-contaminated areas like in Fukushima (Japan).

\section{Conflicts of interest}

There are no conflicts of interest in this work.

\section{Acknowledgements}

We are grateful to Igor Chizhevsky for technical assistance with sampling and Frédéric Coppin for the physico-chemical characterisation of the soil. Thanks to Laurent Garcia-Sanchez for discussion regarding statistical analyses. We are also indebted to Jim Hodges for his invaluable advice on the statistical analyses and the many discussions we had. We also thank Chi-ping Li, and Jim Hodges for comments and correcting the English. This project was supported by a collaborative agreement between International Radiological Laboratory-SSRI (Ukraine) and Institut de Radioprotection et de Sûreté Nucléaire (IRSN, France).

\section{Appendix A. Supplementary data}

Supplementary data to this article can be found online at http://dx. doi.org/10.1016/j.scitotenv.2016.04.006.

\section{References}

Barantal, S., Roy, J., Fromin, N., Schimann, H., Hättenschwiler, S., 2011. Long-term presence of tree species but not chemical diversity affect litter mixture effects on decomposition in a neotropical rainforest. Oecologia 167, 241-252.

Bardgett, R.D., 2005. The Biology of Soil: A Community and Ecosystem Approach. Oxford University Press.

Beaugelin-Seiller, K., Jasserand, F., Garnier-Laplace, J., J-C, Gariel, 2006. Modelling the radiological dose in non-human species: principles, computerization and application. Health Phys. 90, 485-493.

Beresford, N.A., Brown, J., Copplestone, D., Garnier-Laplace, J., Howard, B., Larsson, C.M., Oughton, D., Pröhl, G., Zinger, I. (Eds.), 2007. An Integrated Approach to the Assessment and Management of Environmental Risks From Ionizing Radiation. Description of Purpose, Methodology and Application EC Project Contract No FI6R-CT-2004508847 (https://wikicehacuk/download/attachments/115017395/D-Ericapdf).

Berg, B., Berg, M.P., Bottner, P., Box, E., Breymeyer, A., Calvo de Anta, R., Couteaux, M. Escudero, A., Gallardo, A., Kratz, W., Madeira, M., Mälkönen, E., McClaugherty, C., Meentemeyer, V., Muñoz, F., Piussi, P., Remacle, J., Virzo De Santo, A., 1993. Litter mass loss rates in pine forests of Europe and eastern United States: some relationships with climate and litter quality. Biogeochemistry 20, 127-159.

Berg, B., Ekbohm, G., Söderstrom, B., Staaf, H., 1991. Reduction of decomposition rates of scots pine needle litter due to heavy metal pollution. Water Air Soil Pollut. 59, 165-177.

Bezrukov, V., Møller, A,.P., Milinevsky, G., Rushkovsky, S., Sobol, M., Mousseau T, A., 2015. Heterogeneous relationships between abundance of soil surface invertebrates and radiation from Chernobyl. Ecol. Indic. 52, 128-133.

Cadish, G., Giller, K.E., 1997. Driven by Nature: Plant Litter Quality and Decomposition. CAB Int, Wallingford (432 pp.).

Calabrese, E.J., Baldwin, L.A., 2002. Defining hormesis human and experimental. Toxicology 21, 91-97.

Chapon, V., Piette, L., Vesvres, M.-H., Coppin, F., Le Marrec, C., Christen, R., Theodorakopoulos, N., Février, L., Sviatoslav, L., Martin-Garin, A., Berthomieu, C., Sergeant, C., 2012. Microbial diversity in contaminated soils along the T22 trench of the Chernobyl experimental platform. Appl. Geochem. 27, 1375-1383.

Cornwell, W.K., Cornelissen, J.H.C., Amatangelo, K., Dorrepaal, E., Eviner, VT., Godoy, O. Hobbie, S.E., Hoorens, B., Kurokawa, H., Pérez-Harguindeguy, N., Quested, H.M., Santiago, L.S., Wardle, D.A., Wright, I.J., Aerts, R., Allison, S.D., Van Bodegom, P., Brovkin, V., Chatain, A., Callaghan, T.V., Diaz, S., Garnier, E., Gurvich, D.E., Kazakou, E., Klein, J.A., Read, J., Reich, P.B., Soudzilovskaia, N.A., Vaieretti, M.V., Westoby, M., 2008. Plant species traits are the predominant control on litter decomposition rates within biomes worldwide. Ecol. Lett. 11, 1065-1071.

Dighton, J., Tugay, T., Zhdanova, N., 2008. Fungi and ionizing radiation from radionuclides. FEMS Microbiol. Lett. 281, 109-120. 
Galván, I., Bonisoli-Alquati, A., Jenkinson, S., Ghanem, G., Wakamatsu, K., Mousseau, T.A Møller, A.P., 2014. Chronic exposure to low-dose radiation at Chernobyl favours adaptation to oxidative stress in birds. Funct. Ecol. 28 (6), 1387-1403.

Geras'kin, S.A., Evseeva, T., Oudalova, A., 2013. Effects of long-term chronic exposure to radionuclides in plant populations. J. Environ. Radioact. 121, 22-32.

Geras'kin, S.A., Fesenko, S.V., Alexakhin, R.M., 2008. Effects of non-human species irradiation after the Chernobyl NPP accident. Environ. Int. 34, 880-897.

Gessner, M.O., Swan, C.M., Dang, C.K., McKie, B.G., Bardget, R.D., Wall, D.H., Hättenschwiler, S., 2010. Diversity meets decomposition. Trends Ecol. Evol. 25, 372-380.

IAEA, 1996. 10 years on-the accident at the Chernobyl atomic energy power plant and its consequences. Summary Report on the Post-Accident Review Meeting on the Chernobyl Accident, International Atomic Energy Agency, Vienna; IAEA Safety Series N 75-INSAG-1.

IAEA, 2001. Present and future environmental impact of the Chernobyl accident. International Atomic Energy Agency; IAEA-TECDOC-1240; ISSN 1011-4289.

IAEA, 2006. Environmental consequences of the Chernobyl accident and their remediation: twenty years of experience. Report of the UN Chernobyl Forum Expert Group "Environment" (EGE). International Atomic Energy Agency, Vienna.

Johnson, D., Hale, B., 2004. White birch (Betula papyrifera Marshall) foliar litter decomposition in relation to trace metal atmospheric inputs at metal-contaminated and uncontaminated sites near Sudbury, Ontario and Rouyn-Noranda, Quebec, Canada. Environ. Pollut. 127, 65-72.

Juto, N., 2012. The large scale personal monitoring service using the latest personal monitor glass badge. Proceeding of AOCRP-1, Korea, 20-24 October.

Kashparov, V.A., Lundin, S.M., Zvarych, S.I., Yoshchenko, V.I., Levchuk, S.E., Khomutinin, Y.V., Maloshtan, I.M., Protsak, V.P., 2003e. Territory contamination with the radionuclides representing the fuel component of Chernobyl fallout. Sci. Total Environ. 317, 105-119.

Killham, K., Wainwright, M., 1981. Deciduous leaf litter and cellulose decomposition in soil exposed to heavy metal atmospheric pollution. Environ. Pollut. A 26, 79.

Krivolutsky, D.A., 1996. Dynamics of biodiversity and ecosystems under conditions of radioactive contamination. Dokl. Bolg. Akad. Nauk 347, 166-168.

Krivolutsky, D.A., 2000. Problems of sustainable development and ecological indication in radioactively contaminated areas. Russ. J. Ecol. 31, 233-237.

Lecomte-Pradines, C. J-M, Bonzom, Della-Vedova, C., Beaugelin-Seiller, K., Villenave, C. Gaschak, S., Coppin, F., Dubourg, N., Maksimenko, A., Adam-Guillermin, C., GarnierLaplace, J., 2014. Soil nematode assemblages as bioindicators of radiation impact in the Chernobyl Exclusion Zone. Sci. Total Environ. 490, 161-170.
Maksimova, S, 2002. The effect of radioactive contamination caused by the Chernobyl nuclear accident on Diplopoda communities. Acta Zool. Litua. 12, 90-94.

McEnroe, N.A., Helmisaari, H.S., 2001. Decomposition of coniferous forest litter along heavy metal pollution gradient, south-west Finland. Environ. Pollut. 113, 11-18.

Melillo, J.M., Aber, J.D., Muratore, J.F., 1982. Nitrogen and lignin control of hardwood leaf litter decomposition dynamics. Ecology 63, 621-626.

Møller, A.P., Mousseau, T.A., 2006. Biological consequences of Chernobyl: 20 years on. Trends Ecol. Evol. 21, 200-207.

Møller, A.P., Mousseau, T.A., 2009. Reduced abundance of insects and spiders linked to radiation at Chernobyl 20 years after the accident. Biol. Lett. 5, 356-359.

Mousseau, T.A., Milinevsky, G., Kenney-Hunt, J., Møller, A.P., 2014. Highly reduced mass loss rates and increased litter layer in radioactively contaminated areas. Oecologia $175,429-437$.

Murphy, J.F., Nagorskaya, L.L., Smith, J.T., 2011. Abundance and diversity of aquatic macroinvertebrate communities in lakes exposed to Chernobyl-derived ionizing radiation. J. Environ. Radioact. 102, 688-694.

Prescott, C.E., Zabek, L.M., Staley, C.L., Kabzems, R., 2000. Decomposition of broadleaf and needle litter in forests of British Columbia: influences of litter type, forest type, and litter mixtures. Can. J. For. Res. 30, 1742-1750.

Romanovskaya, V.A., Sokolov, I.G., Rokitko, P.V., Chernaya, N.A., 1998. Effect of radioactive contamination on soil bacteria in the $10-\mathrm{km}$ zone around the Chernobyl nuclear power plant. Microbiology 67, 226-231.

Shestopalov, V.M., 1996. Atlas of Chernobyl Exclusion Zone Kiev. Ukrainian Academy of Science, Ukraine.

Skubala, P., Kafel, A., 2004. Oribatid mite communities and metal bioaccumulation in oribatid species (Acari, Oribatida) along the heavy metal gradient in forest ecosystems. Environ. Pollut. 132, 51-60.

Swift, M.J., Heal, O.W., Anderson, J.M., 1979. Decomposition in Terrestrial Ecosystems. Univ Calif Press, Berkeley (509 pp.).

Waring, R.H., Schlesinger, W.H., 1985. Forest Ecosystems: Concepts and management. Academic Press, Orlando 0127354409 (340 pp.).

Zaitsev, A.S., Gongalsky, K.B., Nakamori, T., Kaneko, N., 2014. Ionizing radiation effects on soil biota: application of lessons learned from Chernobyl accident for radioecological monitoring. Pedobiologia 57, 5-14.

Zheltonozhsky, V., Mück, K., Bondarkov, M., 2001. Classification of hot particles from the Chernobyl accident and nuclear weapons detonations by non-destructive methods. J. Environ. Radioact. 57, 151-166. 


\section{Appendix A.}

\section{Supplementary text: Materials and methods}

\subsection{Study sites}

The Chernobyl Exclusion Zone (CEZ) is located in Northern Ukraine, and corresponds to a $90 \mathrm{~km}$ WE x $45 \mathrm{~km}$ SN enclosed and abandoned area. It is characterized by a continental climate with fairly severe winters and warm summers. Based on data recorded by local meteorological stations mean $( \pm \mathrm{SD})$ ambient temperature was $7.9^{\circ} \mathrm{C} \pm 9.8(\min =-21.0$, $\max$ $=31.9^{\circ} \mathrm{C}$ ), with a January mean of $-2.5^{\circ} \mathrm{C} \pm 3.4$, and a July mean of $21.2^{\circ} \mathrm{C} \pm 3.1$ ).

\subsection{Leaf litter decomposition experiment}

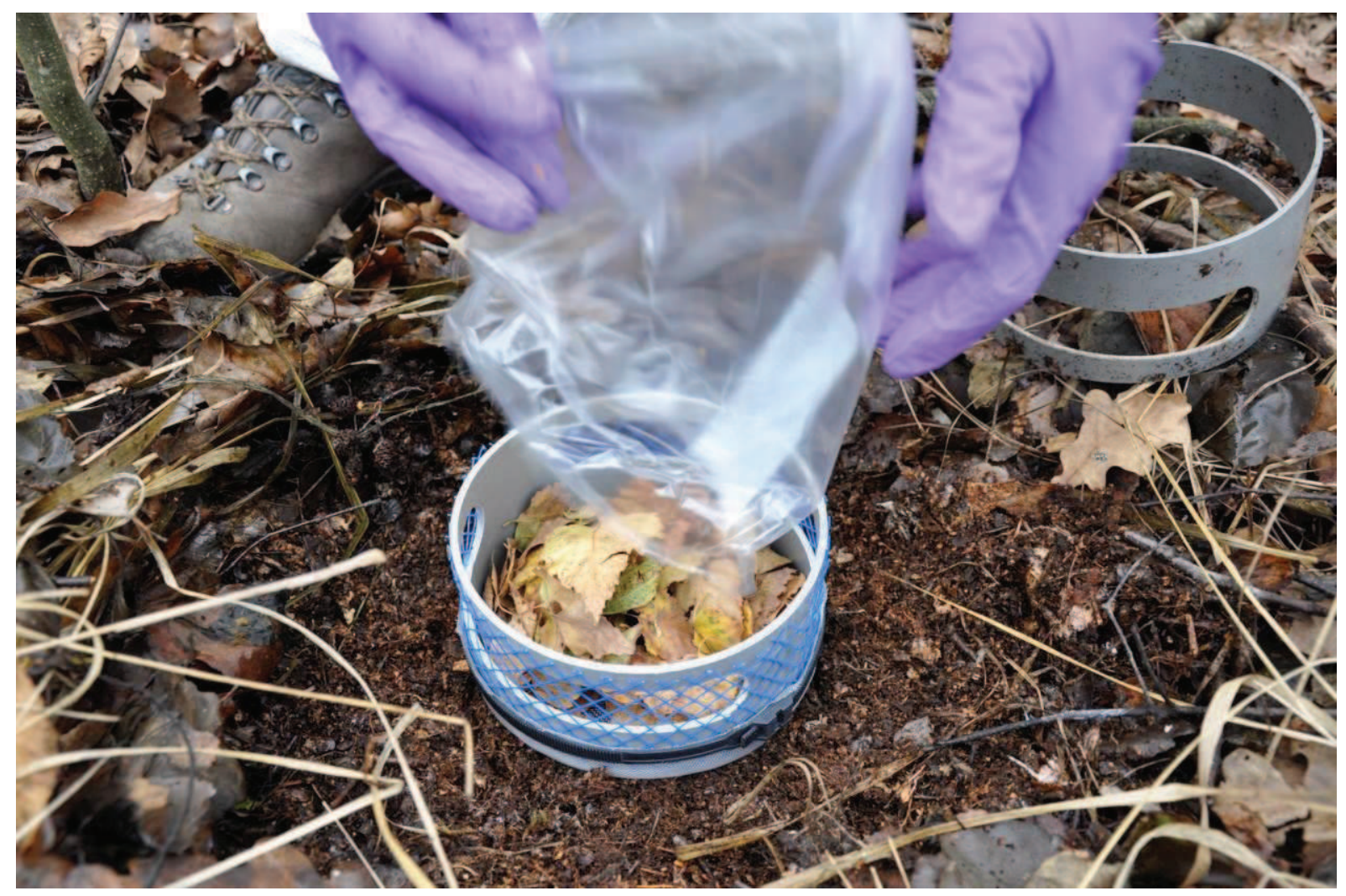



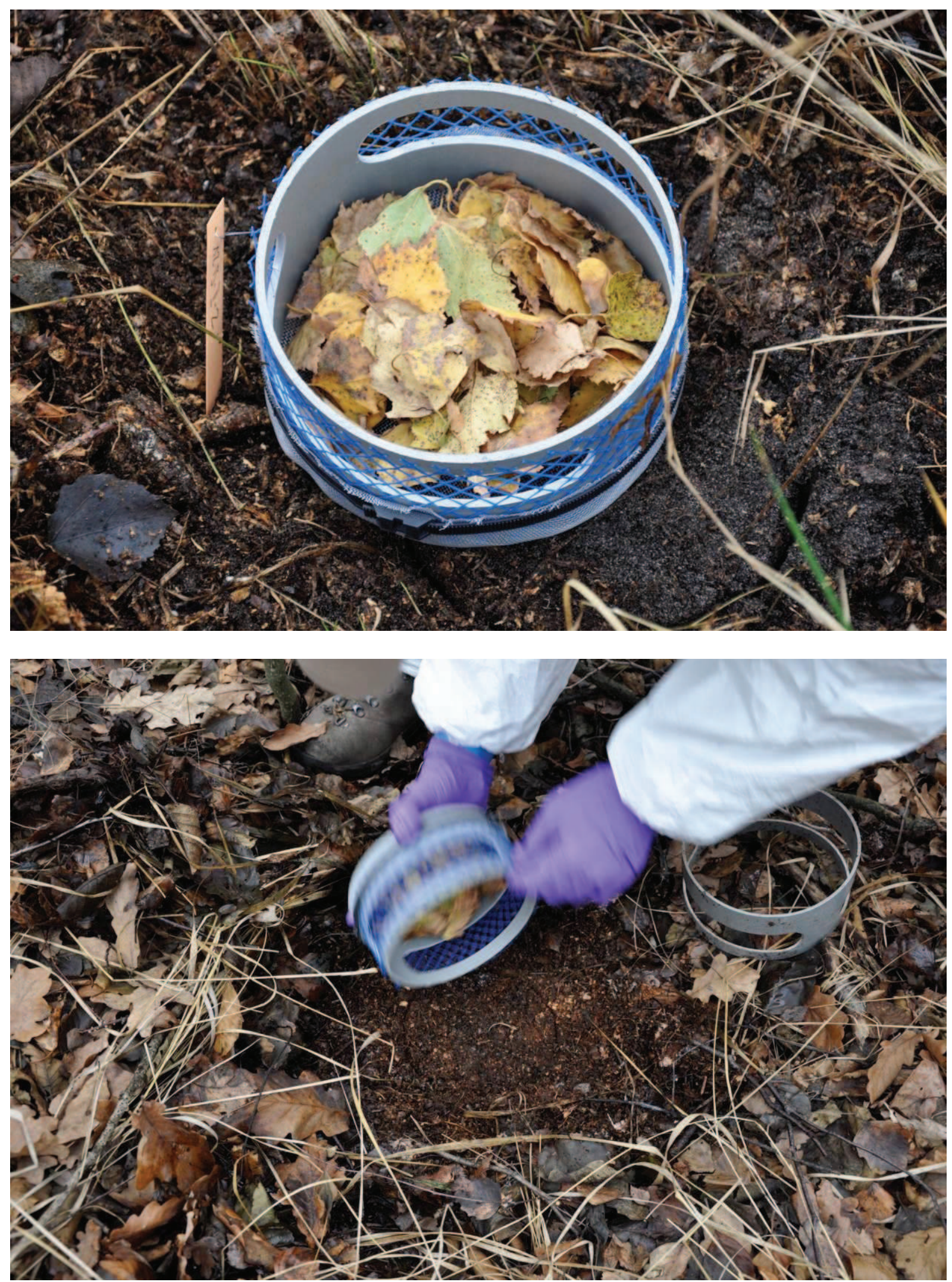

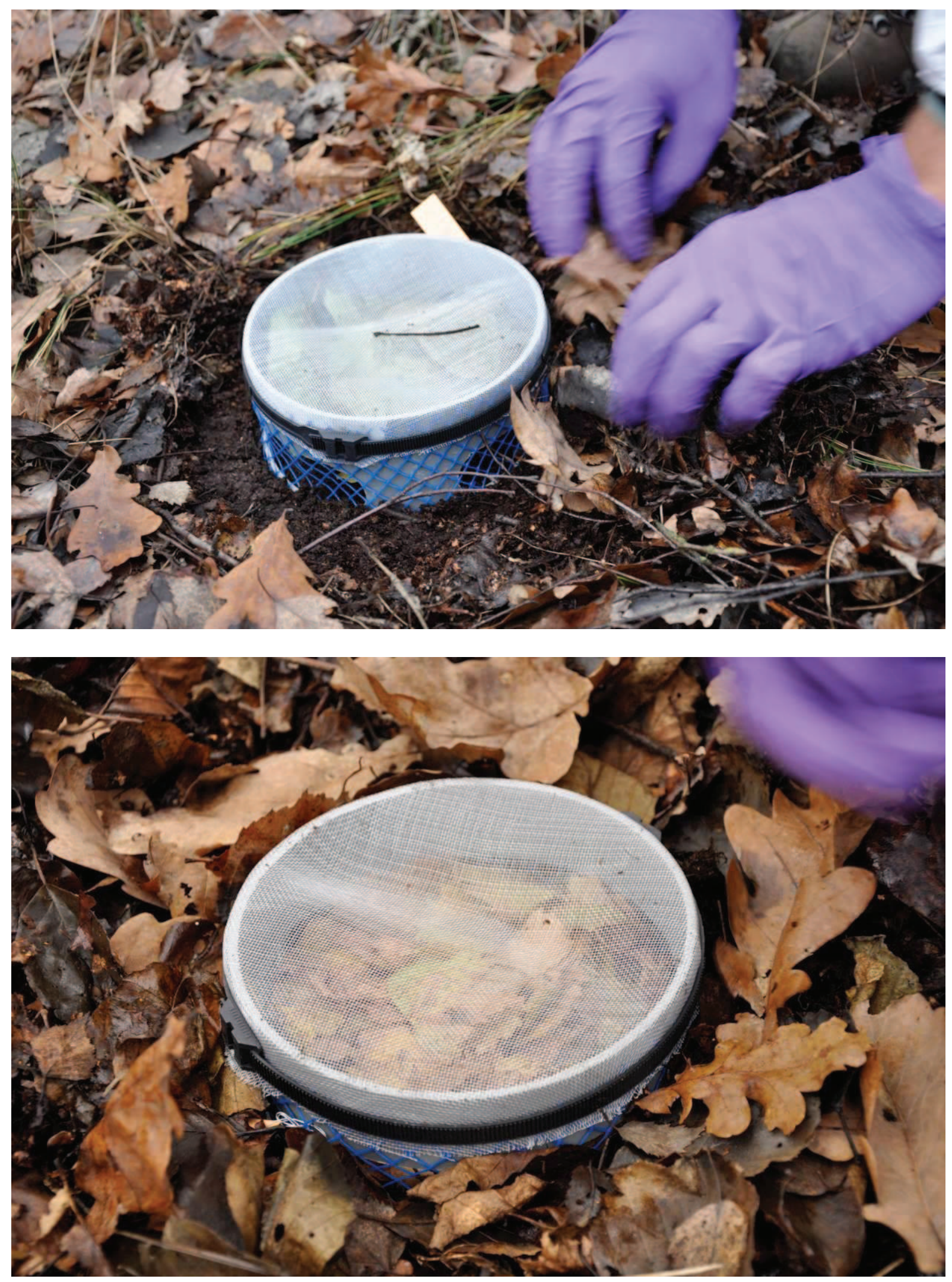


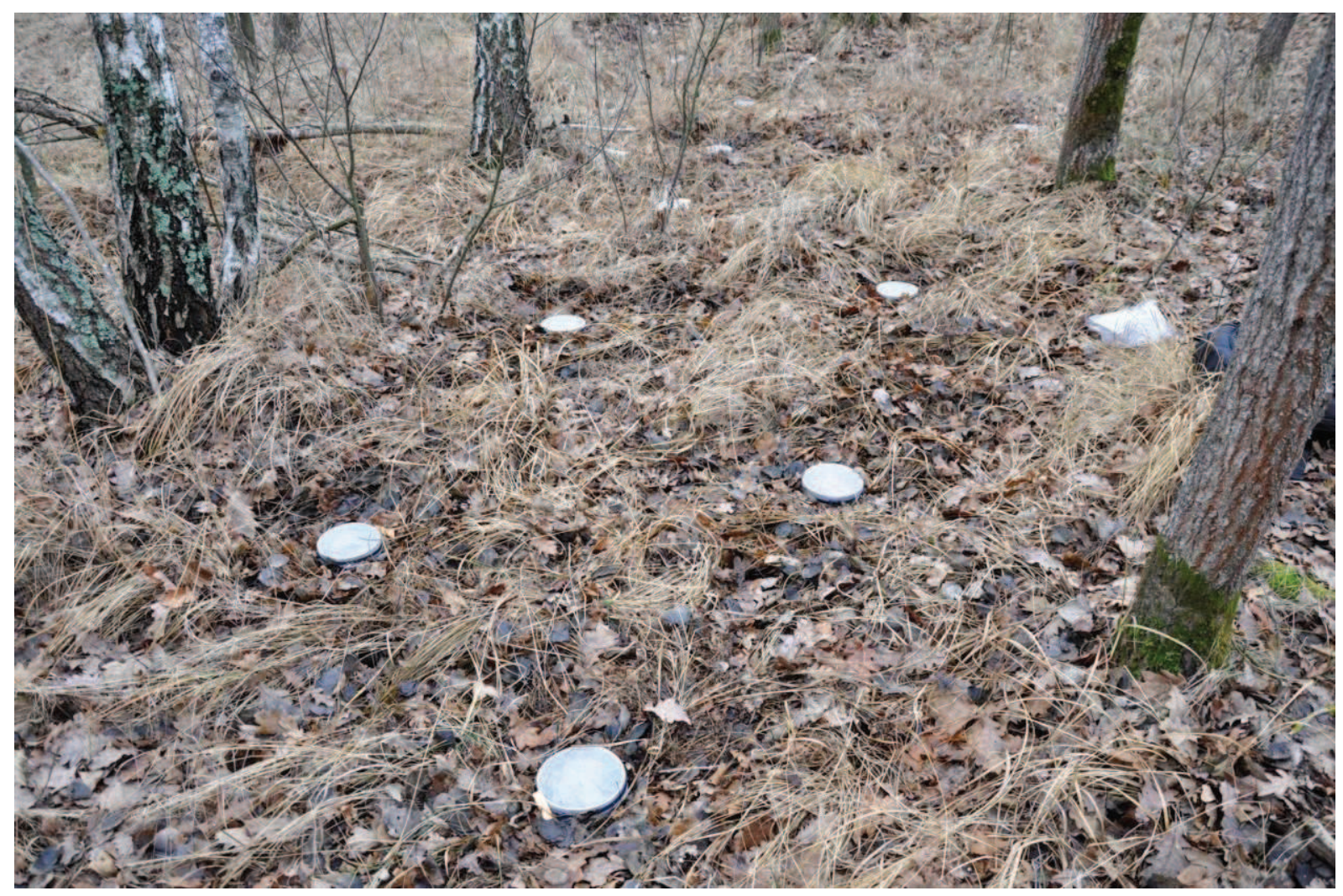

Fig. A.1. The bottom of each microcosm was left open and two 5 x $15 \mathrm{~cm}$ windows covered with $1 \mathrm{~cm}$ nylon mesh were opened on the side at the level of the soil surface, allowing free passage to soil and litter layer invertebrates but avoiding lateral loss of leaf litter. The top of the microcosm was covered with a smaller mesh $(0.05 \mathrm{~cm})$, to avoid contamination with autochthonous litter dropping from the canopy. Microcosms were slightly inserted into the top soil, between 0.5 and $1 \mathrm{~cm}$ with a distance of about $2 \mathrm{~m}$ between individual microcosms. The natural litter removed for microcosm placement was then evenly distributed around the microcosms to provide a continuous litter layer (photos: Jean-Marc Bonzom/IRSN) 

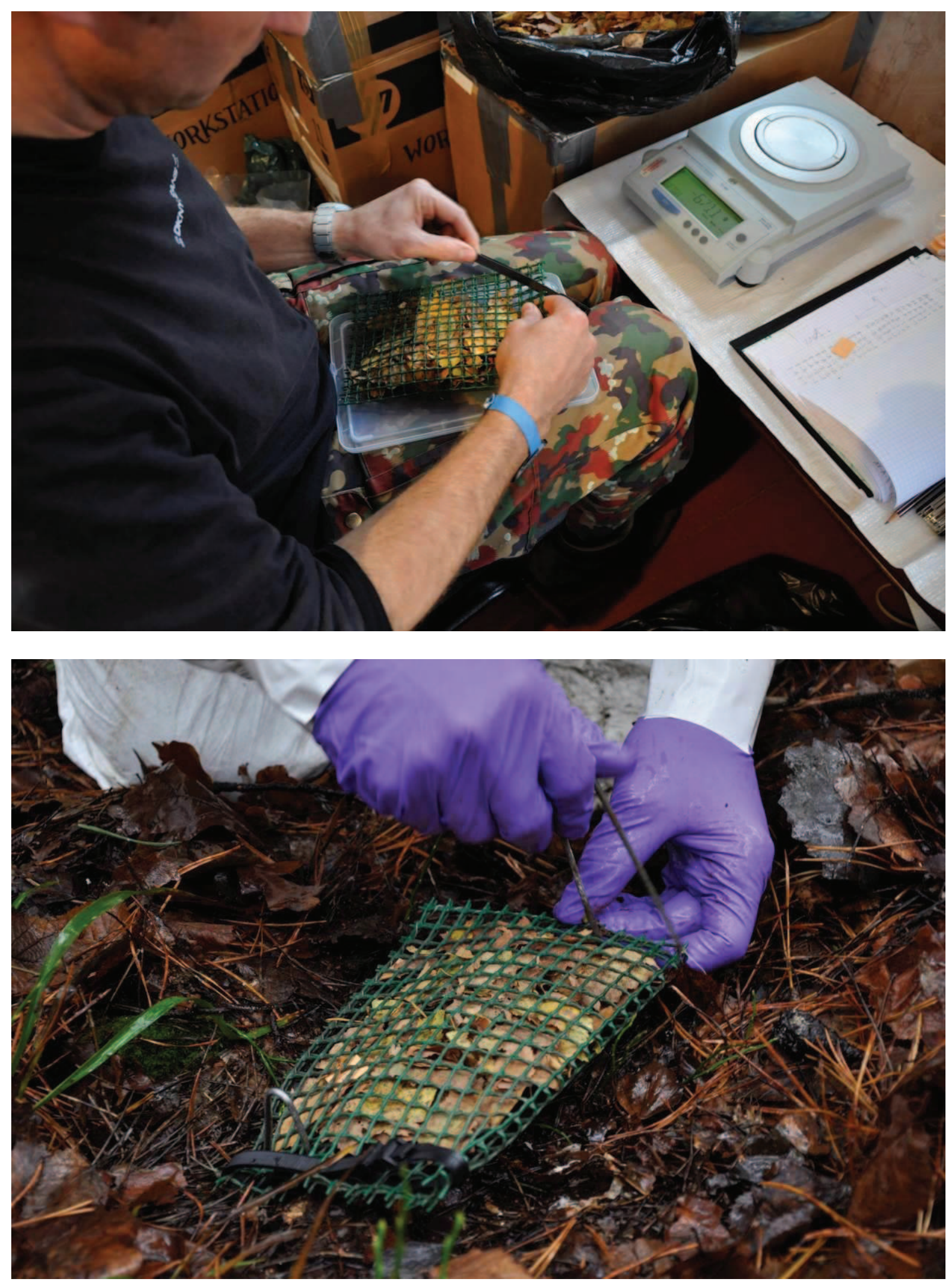


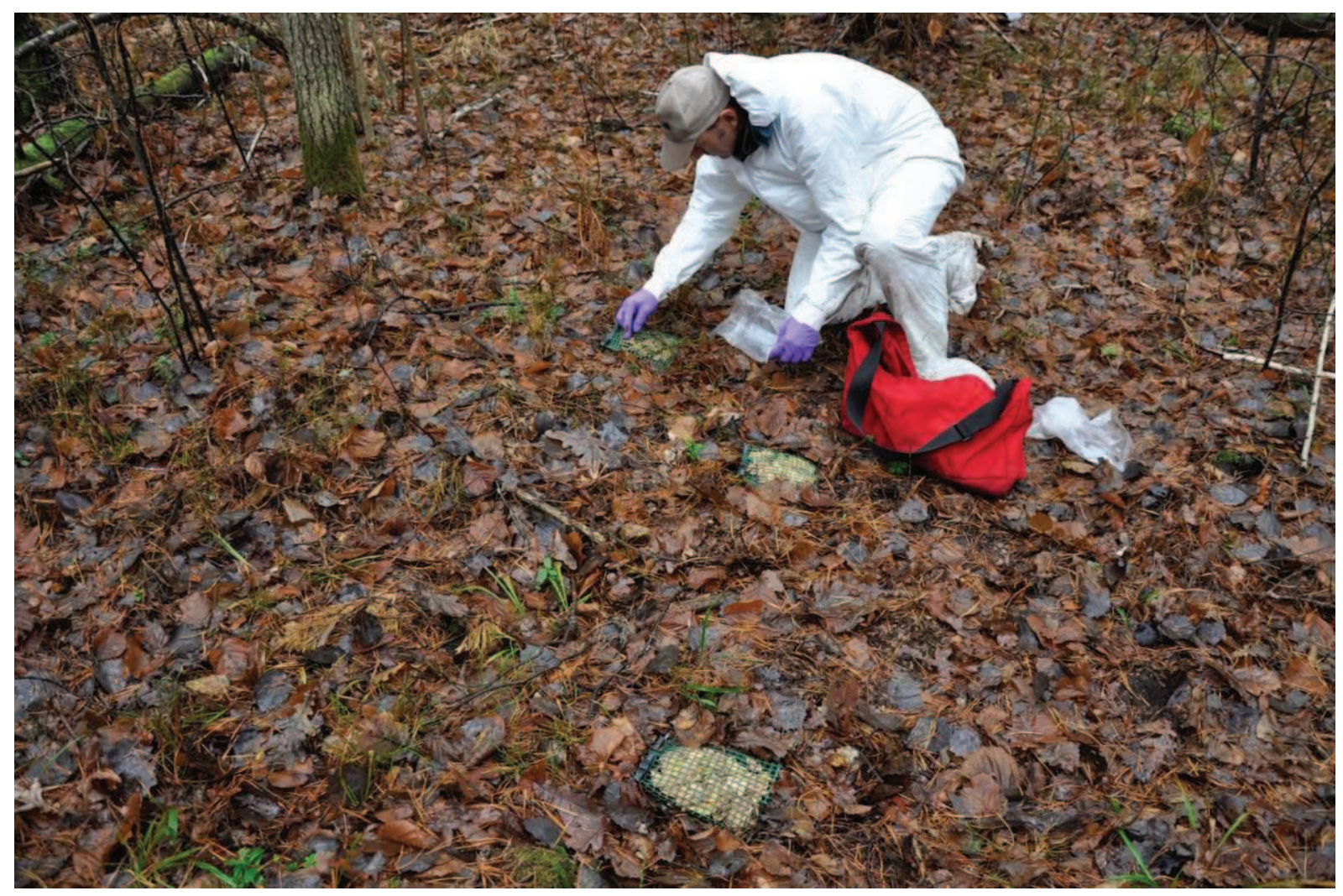

Fig. A.2. The litter bags $(15 \times 15 \mathrm{~cm})$ at site $\mathrm{T}$ were constructed from rigid plastic mesh of $1 \mathrm{~cm}$ mesh width. They were placed flat on soil surface with a distance of about $2 \mathrm{~m}$ between individual litter bags after the natural litter was removed (photos: Jean-Marc Bonzom/IRSN)

\subsection{Soil characteristics}

Soil moisture was determined by drying $100 \mathrm{~g}$ of fresh soil at $105^{\circ} \mathrm{C}$ for $48 \mathrm{~h}$. Soil $\mathrm{pH}$ was measured in the supernatant after 1 hour of addition of $10 \mathrm{~mL}$ distilled water to $1 \mathrm{~g}$ of soil, using a pH glass electrode (WTW-pH320). Soil extractable organic carbon $\left(\mathrm{C}_{\text {org }}\right)$ was determined by dispersing $0.1 \mathrm{~g}$ of soil in a $0.1 \mathrm{M} \mathrm{NaOH}$ solution $(1 \mathrm{~mL})$ for $15 \mathrm{~h}$. After decantation and centrifugation $(10,000 \mathrm{~g}, 10 \mathrm{~min})$ the organic carbon concentration in the supernatant was determined by spectrometry (280 nm; Molecular Devices Spectramax Plus 384 Microplate reader) (Moore 1987). Particle size distribution (PSD) was determined from $0.3 \mathrm{~g}$ of dried soil mixed with $800 \mathrm{~mL}$ of ultrapure water and ultrasonicated for $3 \mathrm{~min}$, using a laser diffraction particle size analyser (Malvern Mastersizer S long bench) (Arriaga et al 
2006). PSD was expressed as DV50 value, which corresponds to the median diameter $(\mu \mathrm{m})$ of the particles.

Activity concentration of ${ }^{137} \mathrm{Cs}$ was measured by gamma spectrometry using a hyper-pure germanium detector (GC 3019, Canberra-Packard), and spectra were analyzed using the Canberra-Packard Genie-2000 software. Estimates of the activity concentrations of ${ }^{90} \mathrm{Sr}$, ${ }^{238} \mathrm{Pu},{ }^{239+240} \mathrm{Pu},{ }^{234} \mathrm{U},{ }^{238} \mathrm{U}$, and ${ }^{241} \mathrm{Am}$ were obtained following the protocols "Analytical Procedures, Eichrom Technologies, Inc. ACW03, SRW01”, after consecutive extraction and separation of isotopes. For details see Lecomte-Pradines et al (2014).

\section{References}

Arriaga F J, Lowery B and Mays M D, 2006. A fast method for determining soil particle distribution using a laser instrument Soil Science 171 663-74

Lecomte-Pradines C, Bonzom J-M, Della-Vedova C, Beaugelin-Seiller K, Villenave C, Gaschak S, Coppin F, Dubourg N, Maksimenko A, Adam-Guillermin C and GarnierLaplace J, 2014. Soil nematode assemblages as bioindicators of radiation impact in the Chernobyl Exclusion Zone Sci. Total Environ. 490 161-70

Moore T R, 1987. An assessment of a simple spectrophotometric method for the determination of dissolved organic carbon in freshwaters New Zeal. J. Mar. and Fresh. 21(4) 585-589 


\section{Supplementary Text: Total dose calculations}

Total radiation dose rates absorbed by each of the four decomposers were obtained summing internal and external contributions, applying the following equations:

$$
\operatorname{TDR}(\mathrm{d})=\Sigma_{\mathrm{i}}[\operatorname{IDR}(\mathrm{d}, \mathrm{i})+\operatorname{EDR}(\mathrm{d}, \mathrm{i})]
$$

Where

- $\quad$ TDR(d) total dose rate absorbed by the decomposer $d$ exposed to all the radionuclides of interest;

- $\operatorname{IDR}(\mathrm{d}, \mathrm{i})$ internal dose rate absorbed by the decomposer $\mathrm{d}$ due to internalization of the radionuclide $\mathrm{i}\left[\mu \mathrm{Gy} \mathrm{h}^{-1}\right]$. The radionuclides measured were ${ }^{137} \mathrm{Cs},{ }^{90} \mathrm{Sr},{ }^{241} \mathrm{Am}$, ${ }^{239,240} \mathrm{Pu},{ }^{238} \mathrm{Pu},{ }^{234} \mathrm{U},{ }^{238} \mathrm{U}$, and daughter products in secular equilibrium with parents (i.e., ${ }^{137 \mathrm{~m}} \mathrm{Ba}$ for ${ }^{137} \mathrm{Cs},{ }^{90} \mathrm{Y}$ for ${ }^{90} \mathrm{Sr},{ }^{234} \mathrm{Th}$ and ${ }^{234 \mathrm{~m}} \mathrm{~Pa}$ for ${ }^{238} \mathrm{U}$ ) were considered in the calculation;

- $\operatorname{EDR}(\mathrm{d}, \mathrm{i})$ external dose rate absorbed by the decomposer $\mathrm{d}$ due to the presence of the radionuclide $\mathrm{i}$ in its neighborhood $\left[\mu \mathrm{Gy} \mathrm{h} \mathrm{h}^{-1}\right]$.

$\operatorname{IDR}(\mathrm{d}, \mathrm{i})=\mathrm{DCC}_{\text {int }}(\mathrm{d}, \mathrm{i}) \times \mathrm{CR}(\mathrm{d}, \mathrm{i}) \times \mathrm{A}_{\text {soil }}(\mathrm{i})$

- $\mathrm{DCC}_{\text {int }}(\mathrm{d}, \mathrm{i})$ dose conversion coefficient for the decomposer $\mathrm{d}$ internally exposed to the radionuclide $\mathrm{i}\left[\mu \mathrm{Gy} \mathrm{h} \mathrm{h}^{-1}\right.$ per $\mathrm{Bq} \mathrm{kg}^{-1}$ of decomposer, fresh mass].

- $\quad \mathrm{CR}(\mathrm{d}, \mathrm{i})$ concentration ratio of the radionuclide $\mathrm{i}$ by the decomposer $\mathrm{d}$ ( $\mathrm{kg}$ soil/ $\mathrm{kg}$ decomposer - total body, fresh mass)

- $\quad \mathrm{A}_{\text {soil }}(\mathrm{i})$ activity of the radionuclide $\mathrm{i}$ in $\operatorname{soil}\left(\mathrm{Bq} \mathrm{kg}^{-1}\right.$ soil) $\operatorname{EDR}(\mathrm{d}, \mathrm{i})=\left[\mathrm{DCC}_{\text {on-soil }}(\mathrm{d}, \mathrm{i}) \times \mathrm{T}_{\text {on-soil }}(\mathrm{d})+\mathrm{DCC}_{\text {in-soil }}(\mathrm{d}, \mathrm{i}) \times \mathrm{T}_{\text {in-soil }}(\mathrm{d})+\mathrm{DCC}_{\text {litter }}(\mathrm{d}, \mathrm{i}) \times\left(1-\left(\mathrm{T}_{\text {on- }}\right.\right.\right.$ soil $\left.\left.\left.(d)+T_{\text {in-soil }}(d)\right)\right)\right] \times A_{\text {soil }}(i)$

- $\quad \mathrm{DCC}_{\text {on-soil }}(\mathrm{d}, \mathrm{i})$ dose conversion coefficient for the decomposer $\mathrm{d}$ located on soil and exposed to the radionuclide i present in soil $\left[\mu \mathrm{Gy} \mathrm{h} \mathrm{h}^{-1}\right.$ per $\mathrm{Bq} \mathrm{kg}^{-1}$ of soil]

- $\quad \mathrm{T}_{\text {on-soil }}(\mathrm{d})$ time fraction spent on soil by the decomposer $\mathrm{d}$ (with $\sum_{i} T_{i}=1$ ) 
- DCC $_{\text {in-soil }}(\mathrm{d}, \mathrm{i})$ dose conversion coefficient for the decomposer $\mathrm{d}$ located in the middle of the soil layer and exposed to the radionuclide i present in soil $\left[\mu \mathrm{Gy} \mathrm{h} \mathrm{h}^{-1}\right.$ per Bq $\mathrm{kg}^{-1}$ of soil]

- $\quad T_{\text {in-soil }}(d)$ time fraction spent in soil by the decomposer $d$

- $\quad \mathrm{DCC}_{\text {litter }}(\mathrm{d}, \mathrm{i})$ dose conversion coefficient for the decomposer $\mathrm{d}$ located in the middle of or on the litter layer and exposed to the radionuclide i present in soil $\left[\mu \mathrm{Gy} \mathrm{h}^{-1}\right.$ per Bq $\mathrm{kg}^{-1}$ of soil]

To run these calculations, usual simplifying assumptions have been adopted with regard to organism characteristics, as follows. Microorganisms are represented by a disk of $1 \mathrm{~cm}$ diameter and $0.5 \mathrm{~mm}$ thickness. Earthworm and nematode are described by revolution ellipsoids, respectively of $25 \times 0.5 \mathrm{~cm}$ and $0.8 \times 0.05 \mathrm{~mm}$. The equivalent ellipsoid corresponding to isopod is $1.5 \times 0.3 \times 0.6 \mathrm{~cm}$. Abiotic media are represented by semi-infinite layers of defined thickness ( $4 \mathrm{~cm}$ for litter and $20 \mathrm{~cm}$ for soil). Media composition and density are indicated in Supplementary Table A.6. Oversimplifying, four different exposure scenarios have been considered, and time spent in each micro-habitat was approximately estimated according to organism habits (Supplementary Table A.2). Dose conversion coefficients were estimated from organism size for each relevant exposure scenario for ${ }^{137} \mathrm{Cs},{ }^{90} \mathrm{Sr},{ }^{241} \mathrm{Am}$, ${ }^{239,240} \mathrm{Pu},{ }^{238} \mathrm{Pu},{ }^{234} \mathrm{U},{ }^{238} \mathrm{U}$, using the IRSN tool EDEN (version 2), and including daughter products as previously described (Supplementary Table A.5). To account for the relative biological effectiveness of the different types of radiation, weighting factors were applied (10 for $\alpha$-radiation, 3 for low- $\beta$ radiation $(E<10 \mathrm{keV})$, and 1 for other $\beta$-radiation and $\gamma$ radiation) (Pröhl et al. 2003).

\section{Reference}

Pröhl G, Brown J, Gomez-Ros J-M, Jones S, Taranenko V, Thørring H, Vives i Batlle J, Woodhead D, 2003. Dosimetric models and data for assessing radiation exposures to biota. Deliverable 3, FASSET project, Contract No FIGE-CT-2000-00102 


\section{Supplementary Table A.1}

Concentration ratio (CR) used for decomposers. The CR is expressed in $\mathrm{kg} d m$ of soil per $\mathrm{kg}$ fm of organism with $\mathrm{CRr}, \mathrm{o}=\frac{C r, o}{C_{r}^{\text {soil }}}($ where $\mathrm{r}$ and o refer to the radionuclide and organism of interest; concentrations are expressed in $\mathrm{Bq}$ per $\mathrm{kg} \mathrm{dm}$ soil and $\mathrm{Bq}$ per fm organism). In the absence of any specific information, we selected the default radionuclide-specific CR values associated with the detritivorous invertebrate organism proposed in the radioecological parameters database of the ERICA Tool (Version 1.2.0) (Brown et al. 2008).

\begin{tabular}{lccccccc}
\hline & ${ }^{137} \mathrm{Cs}$ & ${ }^{90} \mathrm{Sr}$ & ${ }^{241} \mathrm{Am}$ & ${ }^{239,240} \mathrm{Pu}$ & ${ }^{238} \mathrm{Pu}$ & ${ }^{234} \mathrm{U}$ & ${ }^{238} \mathrm{U}$ \\
\hline $\mathrm{CR}$ & 0.106 & 0.343 & 0.10 & 0.0388 & 0.0388 & 0.0104 & 0.0104 \\
\hline
\end{tabular}

\section{Reference}

Brown J E, Alfonso B, Avila R, Beresford N A, Copplestone D, Pröhl G, Ulanovsky A 2008 The ERICA tool. J. Environ. Radioactiv. 99 1371-13 
Supplementary Table A.2

Time fraction each organism spent in each micro-habitat. Brackets shown the thickness of the different microhabitats.

Microorganisms $\quad$ Isopod $\quad$ Nematode $\quad$ Earthworm

\begin{tabular}{lcccc}
\hline On the litter layer $(4 \mathrm{~cm})$ & 0.33 & 0 & 0 & 0 \\
In the middle of the litter layer & 0.33 & 0 & 0.33 & 0.33 \\
On the soil layer $(20 \mathrm{~cm})$ & 0.33 & 1 & 0.33 & 0.33 \\
In the middle of the soil layer & 0 & 0 & 0.33 & 0.33 \\
\hline
\end{tabular}




\section{Supplementary Table A.3}

Summary of ANCOVA results of the effects of average total dose rates (ATDRs) absorbed by decomposers, tree species litter (TreeSpLitter), sampling dates (factors) and soil physico-chemical characteristics (SoilPc; covariate) on leaf litter mass loss at the eleven forest sites.

\begin{tabular}{lclcc}
\hline Source & df & Mean & F-value & P-value \\
& \multicolumn{5}{c}{ Square } & \\
& 10 & 0.023 & 12.039 & $<\mathbf{0 . 0 0 1}$ \\
\hline ATDRs & 1 & 0.646 & 343.893 & $<\mathbf{0 . 0 0 1}$ \\
TreeSpLitter & 1 & 0.639 & 340.230 & $<\mathbf{0 . 0 0 1}$ \\
Sampling dates & 1 & $1.542 \times 10^{-5}$ & 0.008 & 0.928 \\
SoilPc & 10 & 0.002 & 1.164 & 0.332 \\
ATDRs x TreeSpLitter & 10 & 0.009 & 4.710 & $<\mathbf{0 . 0 0 1}$ \\
ATDRs x Sampling dates & 1 & 0.006 & 3.017 & 0.087 \\
Sampling dates x TreeSpLitter & 1 & & & \\
Error & 61 & 0.002 & & \\
Total & 96 & & & \\
\hline
\end{tabular}




\section{Supplementary Table A.4}

Summary of ANCOVA results of the effects of average total dose rates (ATDRs) absorbed by decomposers and soil physico-chemical characteristics (SoilPc; covariate) on birch leaf litter mass loss after 318 days of exposure along a contamination gradient located in a single forest (site $\mathrm{T}$ ).

\begin{tabular}{lcccc}
\hline Source & df & Mean & F-value & P-value \\
& & Square & & \\
& & & & \\
\hline ATDRs & 5 & 0.024 & 5.206 & $<\mathbf{0 . 0 0 1}$ \\
SoilPc & 1 & 0.001 & 0.212 & 0.647 \\
Error & 52 & 0.005 & & \\
Total & 59 & & & \\
\hline
\end{tabular}




\section{Supplementary Table A.5}

Internal and External Dose Conversion Coefficients (DCC) $\left(\mu \mathrm{Gy} \mathrm{h}^{-1}\right.$ per Bq $\left.\mathrm{kg}^{-1}\right)$ for organisms

\begin{tabular}{|c|c|c|c|c|c|c|c|c|}
\hline & & ${ }^{137} \mathrm{Cs}$ & ${ }^{90} \mathrm{Sr}$ & ${ }^{241} \mathrm{Am}$ & ${ }^{239,240} \mathrm{Pu}$ & ${ }^{238} \mathrm{Pu}$ & ${ }^{234} \mathrm{U}$ & ${ }^{238} \mathrm{U}$ \\
\hline \multirow[t]{4}{*}{ Microorganisms } & Internal & $1.31 \times 10^{-5}$ & $7.48 \times 10^{-5}$ & $1.91 \times 10^{-4}$ & $3.80 \times 10^{-4}$ & $1.82 \times 10^{-4}$ & $2.01 \times 10^{-4}$ & $2.79 \times 10^{-4}$ \\
\hline & Ext In litter & $2.39 \times 10^{-12}$ & $3.41 \times 10^{-12}$ & $8.42 \times 10^{-12}$ & $1.23 \times 10^{-11}$ & $6.33 \times 10^{-12}$ & $6.29 \times 10^{-12}$ & $9.47 \times 10^{-12}$ \\
\hline & Ext On soil & $2.95 \times 10^{-12}$ & $3.41 \times 10^{-12}$ & $3.68 \times 10^{-6}$ & $1.38 \times 10^{-6}$ & $1.09 \times 10^{-6}$ & $1.12 \times 10^{-6}$ & $2.13 \times 10^{-6}$ \\
\hline & Ext In soil & $1.06 \times 10^{-4}$ & $1.76 \times 10^{-4}$ & $2.17 \times 10^{-2}$ & $4.06 \times 10^{-2}$ & $2.17 \times 10^{-2}$ & $1.80 \times 10^{-2}$ & $1.48 \times 10^{-2}$ \\
\hline \multirow[t]{2}{*}{ Isopod } & Internal & $3.58 \times 10^{-4}$ & $1.04 \times 10^{-3}$ & $3.14 \times 10^{-2}$ & $5.90 \times 10^{-2}$ & $3.14 \times 10^{-2}$ & $2.73 \times 10^{-2}$ & $2.48 \times 10^{-2}$ \\
\hline & Ext On soil & $5.87 \times 10^{-5}$ & $3.36 \times 10^{-4}$ & $5.83 \times 10^{-6}$ & $7.68 \times 10^{-6}$ & $4.96 \times 10^{-6}$ & $2.76 \times 10^{-6}$ & $2.59 \times 10^{-4}$ \\
\hline \multirow[t]{4}{*}{ Nematode } & Internal & $3.16 \times 10^{-5}$ & $9.19 \times 10^{-5}$ & $1.40 \times 10^{-2}$ & $2.88 \times 10^{-2}$ & $1.39 \times 10^{-2}$ & $1.48 \times 10^{-2}$ & $1.51 \times 10^{-2}$ \\
\hline & Ext In litter & $4.89 \times 10^{-5}$ & $2.78 \times 10^{-8}$ & $9.96 \times 10^{-7}$ & $3.12 \times 10^{-8}$ & $2.18 \times 10^{-8}$ & $2.27 \times 10^{-8}$ & $1.51 \times 10^{-6}$ \\
\hline & Ext On soil & $9.39 \times 10^{-4}$ & $1.08 \times 10^{-3}$ & $8.58 \times 10^{-3}$ & $1.47 \times 10^{-2}$ & $8.58 \times 10^{-3}$ & $6.04 \times 10^{-3}$ & $4.78 \times 10^{-3}$ \\
\hline & Ext In soil & $3.24 \times 10^{-4}$ & $1.08 \times 10^{-3}$ & $1.38 \times 10^{-2}$ & $2.42 \times 10^{-2}$ & $1.39 \times 10^{-2}$ & $1.00 \times 10^{-2}$ & $8.09 \times 10^{-3}$ \\
\hline \multirow[t]{4}{*}{ Earthworm } & Internal & $3.75 \times 10^{-4}$ & $1.20 \times 10^{-3}$ & $3.14 \times 10^{-2}$ & $5.90 \times 10^{-2}$ & $3.14 \times 10^{-2}$ & $2.73 \times 10^{-2}$ & $2.49 \times 10^{-2}$ \\
\hline & Ext In & $4.80 \times 10^{-5}$ & $5.33 \times 10^{-5}$ & $9.13 \times 10^{-7}$ & $1.75 \times 10^{-8}$ & $1.10 \times 10^{-8}$ & $1.32 \times 10^{-8}$ & $4.08 \times 10^{-5}$ \\
\hline & Ext On soil & $5.70 \times 10^{-5}$ & $2.22 \times 10^{-4}$ & $8.50 \times 10^{-6}$ & $1.09 \times 10^{-5}$ & $7.04 \times 10^{-6}$ & $3.93 \times 10^{-6}$ & $1.74 \times 10^{-4}$ \\
\hline & Ext In soil & $1.29 \times 10^{-4}$ & $3.16 \times 10^{-4}$ & $1.63 \times 10^{-4}$ & $2.73 \times 10^{-4}$ & $1.61 \times 10^{-4}$ & $1.10 \times 10^{-4}$ & $3.19 \times 10^{-4}$ \\
\hline
\end{tabular}

Ext In litter: In the middle of the litter layer; Ext On soil: On the soil layer; Ext In soil: In the middle of the soil 


\section{Supplementary Table A.6}

Elemental composition ( $\%$ of the total mass), and density of soil, leaf litter, air, decomposer (1)

\begin{tabular}{|c|c|c|c|c|}
\hline & Soil & Leaf litter & Air & Decomposer \\
\hline$\overline{\mathrm{Al}}$ & 5 & n.d. & n.d. & n.d. \\
\hline $\mathrm{Ar}$ & n.d. & n.d. & 1.3 & n.d. \\
\hline $\mathrm{C}$ & 1.6 & $1.1 \times 10^{1}$ & $1.4 \times 10^{-2}$ & $1.4 \times 10$ \\
\hline $\mathrm{Ca}$ & 4.1 & $5.8 \times 10^{-1}$ & n.d. & n.d. \\
\hline $\mathrm{Cl}$ & n.d. & n.d. & n.d. & $1.0 \times 10^{-1}$ \\
\hline $\mathrm{Fe}$ & 1.1 & n.d. & n.d. & n.d. \\
\hline $\mathrm{H}$ & 2.1 & 8.7 & $6.4 \times 10^{-2}$ & $1.0 \times 10^{1}$ \\
\hline $\mathrm{K}$ & 1.3 & $1.7 \times 10^{-1}$ & n.d. & $4.0 \times 10^{-1}$ \\
\hline $\mathrm{Mg}$ & n.d. & $8.0 \times 10^{-2}$ & n.d. & n.d. \\
\hline $\mathrm{N}$ & n.d. & $8.2 \times 10^{-1}$ & $7.5 \times 10$ & $3.4 \times 10$ \\
\hline $\mathrm{Na}$ & n.d. & $3.0 \times 10^{-2}$ & n.d. & $1.0 \times 10^{-1}$ \\
\hline $\mathrm{O}$ & $5.8 \times 10$ & $7.8 \times 10$ & $2.4 \times 10$ & $7.1 \times 10$ \\
\hline $\mathrm{P}$ & n.d. & $7.1 \times 10^{-1}$ & n.d. & $2.0 \times 10^{-1}$ \\
\hline $\mathrm{S}$ & n.d. & $1.0 \times 10^{-1}$ & n.d. & $3.0 \times 10^{-1}$ \\
\hline $\mathrm{Si}$ & $2.7 \times 10$ & $1.0 \times 10^{-2}$ & n.d. & n.d. \\
\hline$\left(\mathrm{g} / \mathrm{cm}^{3}\right)$ & 1.6 & $6.3 \times 10^{-3}$ & $1.2 \times 10^{-3}$ & 1 \\
\hline
\end{tabular}

(1) ICRU (International Commission on Radiation Units and Measurements), 1992, Photon, Electron, Proton and Neutron Interaction Data for Body Tissues (Nuclear Technology Publishing, Ashford, UK), Report 46.

n.d.: not determinated 